\title{
"Unwarranted" Wage Changes and the Return on Capital
}

\author{
Margarita Katsimi \\ Sarantis Kalyvitis \\ Thomas Moutos
}

CESIFO WORKING PAPER NO. 2804

CATEGORY 4: LABOUR MARKETS

SEPTEMBER 2009

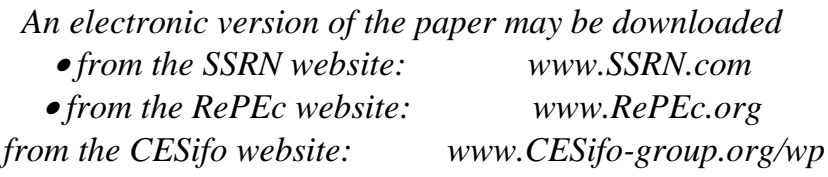




\title{
"Unwarranted" Wage Changes and the Return on Capital
}

\begin{abstract}
Casual empiricism suggests that "unwarranted" wage changes, defined as the part of wage growth that is not explained by changes in labour productivity, are negatively associated with the return on capital. The main point of this paper is to show that "unwarranted" wage changes have no causal effect on capital return. To this end, we show that standard theoretical models, in which "unwarranted" wages changes and the return on capital are endogenously determined, do not necessarily predict a negative association between them. We then estimate aggregate net return on capital equations using panel data for 19 OECD countries for the period 1970-2000 in which we account for the endogeneity of "unwarranted" wage changes by exploiting variations in institutional and labour market characteristics. We find that "unwarranted" wage changes do not affect the return on capital. This result remains robust to alternative empirical specifications and to alternative definitions of profitability and "unwarranted" wage changes. An implication of our findings is that standard calls for reforms aiming at wage moderation following the appearance of "unwarranted" wage changes are not always justified.
\end{abstract}

JEL Code: E24, E25.

Keywords: capital return, profits, "unwarranted" wages, productivity, endogeneity.

\author{
Margarita Katsimi \\ Athens University of Economics and Business \\ Department of International and European Economic Studies \\ Patision Str 76 \\ Greece - Athens 10434 \\ mkatsimi@aueb.gr
}

\author{
Sarantis Kalyvitis \\ AUEB \\ skalyvitis@aueb.gr
}

\author{
Thomas Moutos \\ $A U E B$ \\ tmoutos@aueb.gr
}

September 2009

We have benefited from comments and suggestions by Costas Arkolakis, Leif Danziger, George Economides, Bob Hart, Marc-Andreas Muendler, Apostolis Philippopoulos, Vassilis Sarantides, Vangelis Vassilatos, Eugenia Vella, and seminar participants at the Athens University of Economics and Business, and the CESifo Area Conference on Employment and Social Protection, Munich, May 2009. 


\section{Introduction}

From Smith, Ricardo, and Marx, through to Keynes, Kalecki, and Schumpeter, and to modern endogenous growth theorists, economists have agreed that the long-run performance of capitalist economies is organized around the pursuit of profits. ${ }^{1}$ The importance of profits for the "medium run" has also been recognized by influential studies regarding, for instance, developments in the labour market (e.g. Sachs, 1979; Bruno and Sachs, 1985; Blanchard, 1997). A common thread of these studies is the evolution of factor shares following the oil price shocks in the 1970s and its implications for the rise of European unemployment. Bruno (1984) has demonstrated that an increase in oil prices can be considered as an autonomous technical regress that necessitates a decrease in real wages to avoid a rise in unemployment. The failure of real wages to adjust to the adverse productivity developments in many European countries triggered the emergence of a "real wage gap" (defined as the difference between the observed real wage and the estimated full-employment real wage) accompanied by a decline in profitability and the capital share.

Among the international economic organizations, the OECD has been particularly keen in noting the importance of profitability for the future evolution of macroeconomic aggregates: “... high levels of corporate profitability across the OECD area may entail favourable surprises for capital formation, employment and growth" (OECD, 2006, p.2). Combining this with the observation that the strong rise in profit margins is associated with muted real wage developments, the OECD draws the conclusion that “...the current pattern of real wage increases in excess of productivity growth could compromise future economic performance [...] It is important that wage settlements [...] reflect productivity developments" (op.cit. p.101, italics added).

The simple bivariate relationship between profits and "unwarranted" wage changes, measured as the

\footnotetext{
${ }^{1}$ Perhaps the most emblematic analysis of the role of profits in the evolution of capitalist economies has been given by Ricardo. In his model, the distribution of income between land rents, profits and (subsistence) wages determines the economy's evolution. As long as the profit rate is above what capitalists would deem as acceptable, capital will be accumulated. This process will come to a halt when, due to diminishing returns, the profit rate falls and capital accumulation and growth come to an end (i.e., Ricardo's "stationary state"). Keynes considered profits as the "mainspring of change", whereas for the modern endogenous growth theory, growth-enhancing innovations stem from the profit-seeking efforts of entrepreneurs (see, for instance, Aghion and Howitt, 1998).
} 
part of wage growth that is not explained by changes in labour productivity, is summarized in Figure 1, which plots the 5-year averages of the net return on capital and our estimates of unwarranted wages from OECD economies over the period 1970-2000. In accordance with the theoretical framework described earlier on and conventional wisdom (as exemplified by the OECD), Figure 1 indeed shows that there is a clear negative association between the two variables. In contrast, this paper presents detailed evidence that there is no causal association between unwarranted (or "excessive") wage changes and the return on capital or profitability. ${ }^{2}$ This finding implies that the usual policy advice given by international economic organizations to countries experiencing unwarranted wages changes to moderate wage growth in order to reflect productivity is not always justified.

The main idea driving the empirical methodology adopted in this paper is that both wages and the return on capital may be jointly determined by changes in the economic, political, and institutional environment (see, among others, Christofides and Oswald, 1992; Blanchflower and Oswald, 1994; Rodrik, 1999; Blanchard and Giavazzi, 2003). In particular, with regard to changes in the economic environment a number of theoretical developments, like implicit contract theory and firm-union bargaining theories, suggest that the pressure for wage increases above productivity changes will be particularly intense in countries (or times) of higher profits. In this vein, Mumford and Dowrick (1994) have noticed that "observed profitability is an endogenous variable, affected directly by wage outcomes and perhaps indirectly through efficiency wage effects, so single equation estimates of the relationship between wages and financial performance may be subject to simultaneous equation bias [...] This result is consistent with the prediction that exogenous shocks to the wage influence the profit term and bias the estimating parameter downwards". Hence, as long as there is some sharing of the rents generated by the employment relationship, these common shocks will affect both business conditions and the wage negotiation process. Rent sharing is at the core of both the firm-union bargaining models (e.g. Layard et al., 1991,

\footnotetext{
${ }^{2}$ In the remainder of the paper the terms the terms "unwarranted" and "excessive" wages, as well as profitability and return on capital will be used interchangeably. It should be stressed that, although in our empirical analysis we use various measures for unwarranted wage changes, we avoid constructing a "real wage gap" variable in the spirit of Bruno and Sachs (1985) as this is unduly restricted to both a perfectly competitive interpretation of the data and to a presumption of knowledge of the "equilibrium" real wage rate (see Bean, 1994, for more details).
} 
Blanchflower et al., 1996) and search-and-matching models (e.g. Pissarides, 2000). ${ }^{3}$

Similarly, changes in both profits and unwarranted wage changes can be caused by changes in the structural features of the labour market, like the composition of the labour force or working conditions. An important (and highly political) instance of a change in working conditions is the regulation of working time. In response to the rise in unemployment in many OECD countries in the late 1970s, the idea that a redistribution of what was considered to be a fixed amount of work among a larger number of persons gained ground as a sensible alternative (called by many economists the lump of labour fallacy). Some countries did in fact promote such measures - mainly the reduction of the institutionally set standard hours of work per week. The effect of such measures on worker productivity, wages, employment, and profitability has been a widely studied area, which is comprehensively surveyed by Hart (1992). The relevance of institutional/political factors has also been studied extensively in the literature. Card (1996) and Card and DiNardo (2002) study how de-unionization and the erosion of the real value of the minimum wage have affected the evolution of the wage distribution in the United States. Blau and Kahn (1999, 2000) review and examine how differences in the degree of centralization of the bargaining process across countries have impacted on the shape of the bottom end of the wage distribution. Rodrik (1999) documents the influence of the political regime on wage formation across countries. Although these papers do not deal with the influence of these institutional/political changes on the return on capital, they highlight the independent influence of these factors on wages beyond the impact of productivity developments. More importantly, they also imply that the negative relationship between the return on capital and unwarranted wage changes observed in the data will consequently reflect an equilibrium response to changes in structural and/or institutional characteristics of the economy resulting in a spurious correlation driven through the particular labour market channels.

To address these issues we investigate the impact of excessive wage changes on various measures of profitability by estimating aggregate profit equations using panel data for 19 OECD countries for the

\footnotetext{
${ }^{3}$ The implicit contract literature (Baily, 1974; Azariadis, 1975) also implies that there can be a positive co-movement between wages and profits per employee as a result of risk-sharing, if both workers and firms are risk averse (Blanchflower and Oswald, 1994).
} 
period 1970-2000. We show that in non-instrumental regressions excessive wages are found to exert a negative impact on capital return and profits. In contrast to this finding, the estimated effect of excessive wages on capital return and profits changes starkly when we account for the endogeneity of unwarranted wage changes. We are able to show that once we instrument out unwarranted wage changes by exploiting variations in institutional and labour market characteristics, the relationship between profits and excessive wages evaporates. This result is robust to a number of sensitivity tests, including various definitions of profitability and excessive wage changes.

The rest of the paper is organized as follows. Section 2 presents some theoretical considerations regarding the endogeneity of unwarranted wage changes and the return on capital. Section 3 outlines the empirical setup and describes the data. Section 4 presents the empirical results and section 5 discusses some sensitivity tests. Finally, section 6 offers some concluding remarks.

\section{Theoretical considerations}

In this section we briefly review some arguments on the lack of a causal, and negative, relationship between unwarranted wage changes and the return on capital. It is worth reiterating at this point that we are not claiming that a deux ex machina rise in wages will not adversely affect profitability (at least in a partial equilibrium framework); instead, we show that once we take into account the possibility that both wage changes and profitability are jointly determined in response to changes in the economic/institutional environment, the co-movement between the two variables is far from unambiguous.

Why real wage changes may not fully reflect changes in labour productivity? Indeed, a perfectly competitive model, under a Cobb-Douglas technology, does not allow for a divergence between wages and labour productivity, since in this case the marginal product of labour is a fixed proportion of labour productivity with the degree of proportionality being equal to the labour share. Hence, wages are equal to the marginal product and maintain their proportionality to labour productivity. However, if the economy's production structure is not adequately described by a Cobb-Douglas function, then changes in underlying structural or institutional parameters may raise both wages relative to productivity and the return on 
capital even under perfectly competitive conditions.

Consider, for instance, the response of a firm to changes in how labour effort is affected by wage incentives. Assume now a change in the social/institutional environment such that, at a given gap between the wage paid by the firm and the alternative wage rate, the elasticity of effort with respect to the premium the firm pays over the alternative wage increases. ${ }^{4}$ How are we to interpret changes in this elasticity (call it $\theta$ ), or what are real-world structural/institutional changes which may influence its value? The quality of labor relations is an important variable in this respect. We would expect that an intensification of conflict in industrial relations would affect the effort that a given value of the relative wage differential would procure. A change in the composition of the labour force is another possible factor that may affect the value of the elasticity of effort with respect to the "relative wage differential". For example an increase in the proportion of teenagers in the labour force may affect the "economy-wide" value of $\theta$, as teenagers may dislike a faster moving production line more than prime-aged workers. Similarly, to the extent that sectoral reallocation of economic activity involves changes in the typical working environment (e.g. clerks versus construction workers), the "economy-wide" value of $\theta$ will also be affected. In the Appendix we present an example of an efficiency-wage model in which we study the effects of changes in the value of $\theta$ on unwarranted wage changes and the return on capital. The example is based on using a CES production function, which does not constrain the marginal product of labour to be a fixed percentage of the average product, thus allowing for the ratio of wages, which are equal to the marginal product, to labour productivity to vary in response to changes in both the labour and capital inputs. We find that changes in the elasticity of effort induce firms to change their wages and use of factor inputs so that a positive co-movement between excessive wages and the return on capital can be generated. ${ }^{5}$

The lack of a causal (and necessarily negative) relationship between excessive wage changes and the

\footnotetext{
${ }^{4}$ The political scientist Ronald Inglehart $(1997,2008)$ has documented shifts in many industrial countries away from the disciplined, self-denying, and achievement-oriented norms of industrial society (which is associated with deference to tradition and the attachment to organizational goals) towards the fulfilment of personal goals and individual self-expression at the cost of neglecting the objectives of broader entities.

${ }^{5}$ The direction of the co-movement (whether both excessive wages and the return on capital fall, or both rise, in response to a rise in $\theta$ ) is influenced by the elasticity of substitution.
} 
return on capital may also be present in an imperfectly competitive framework. In particular, if the labour market is not perfectly competitive, wages need not be equal to the marginal product of labour. Figure 2 portrays the average and marginal product of labour schedules for a firm that does not pay a wage equal to the marginal product. Instead, we assume that, for example due to the presence of trade unions, the workers are able to appropriate some rents and the wage, $w_{0}$, is between the marginal and average product of labour at employment level $N_{0}{ }^{6}{ }^{6}$ Total profits are initially equal to $N_{0}\left(A P_{0}-W_{0}\right)$. The dotted schedule, known as the rent division curve (Booth, 1995), which maintains at all employment levels its relative vertical distance between the average and marginal product schedules, can be thought of as tracing out the resulting wage rate under constant relative bargaining power between the firm and the union. ${ }^{7}$ Consider now a new equilibrium with wages and employment equal to $W_{1}$ and $N_{1}$, respectively. The movement from $\left(w_{0}, N_{0}\right)$ to $\left(w_{1}, N_{1}\right)$ can be triggered in a Nash bargaining framework by shifts of both the contract curve (e.g. due to changes in the minimum wage) and/or shifts along the (new) contract curve (e.g. due to a change in relative bargaining power). For example, the new $\left(w_{1}, N_{1}\right)$ pair may result from the combination of a rise in union power, which is expected to shift the wage closer to the average product, and a fall in the minimum wage, which is expected to increase employment by shifting the origin of a positively-sloped contract curve downwards and to the right. If the (percentage) drop in wages is relatively smaller than the drop in labour productivity $(A P)$, then we have an unwarranted wage increase. Yet, as the Figure shows, the rise in the ratio of wages to productivity can be associated with a rise in profits (and the return on capital, since the capital stock is assumed fixed in this example), which are now equal to $N_{1}\left(A P_{1}\right.$

\footnotetext{
${ }^{6}$ Although there is no dispute as to whether some workers are paid above their marginal products, there is some dispute about whether some workers are paid below their marginal product (see, for instance, Frank, 1984; Machin et al., 1993; Hellerstein et al., 1999).

${ }^{7}$ When the bargaining power is symmetrically distributed between the two parties, the Nash bargaining framework implies a bargained wage that is the arithmetic mean between the average and the marginal product of labour (see, McDonald and Solow, 1991). In this case, the dotted schedule (rent division curve) would be vertically equidistant between the marginal and average product schedules at all employment levels. If the bargaining power is asymmetrically distributed, then the wage is a weighted average of the average and the marginal product, the weights being equal to the relative bargaining power of each party; the higher is the (relative) power of the union, the closer will be the rent division curve to the average product schedule. We note that the rent division curve traces out the wage-employment combinations that result from shifts in the position of the contract curve (e.g., due to a change in alternative opportunities for workers) for a non-changing bargaining power.
} 
$\left.-W_{1}\right)$. Thus, a negative co-movement between unwarranted wage changes on the return on capital is not certain a-priori.

Beyond these partial equilibrium examples, it is also important to take into account of possible macroeconomic interactions. To this purpose let us assume that the profitability of firms in a particular sector declined following an unwarranted wage shock. Can we infer that an unwarranted wage shock would be harmful to economy-wide profitability? Not necessarily, as the profitability of the non-affected firms may have risen due to a switch in demand towards their products, driven for example by differential cost and price developments between affected and non-affected firms or sectors. Alternatively, the rise in wage income may have contributed to the emergence of new firms within a sector or of entire sectors, which depend on mass consumption demand in order to be profitable. ${ }^{8}$ Moreover, as Murphy et al. (1989) have demonstrated, the payment of a wage premium to workers of would-be technologically advanced firms can make profitable the adoption of such superior technologies, leading to an economy-wide increase in profits despite the appearance of excessive wage increases at the firm level. It is therefore the potential influence of these intersectoral repercussions that one hopes to also take into account when examining aggregate profit equations.

\section{Determining profits and unwarranted wage changes}

\subsection{Empirical setup}

Although several studies have examined the determinants of profitability at the industry level using firmlevel of sectoral-level data, surprisingly the existing empirical literature aiming at estimating aggregate

\footnotetext{
${ }^{8}$ See, for example, Matsuyama (2002), for the development of an argument along these lines. Malley and Moutos (2006) present another way in which a switch in demand in advanced OECD countries could be instrumental in this respect. They present a model in which developed countries have comparative advantage in the production of highquality varieties. An unwarranted wage increase in this context this will increase (reduce) demand for domestically produced (imported) goods, thus potentially offsetting the decline in profits that unwarranted wage increases entail. The role of inequality could also prove an important determinant of the effect of excessive wage increases in this context, since, to the extent that reductions in inequality are associated with excessive wage increases, agents can switch demand away from low-quality imported varieties and towards high-quality, domestically produced varieties.
} 
profit equations is quite limited and is only indirectly related to the issue of unwarranted wage changes. ${ }^{9}$ Finkel and Tuttle (1971) were the first who attempted to identify empirically the determinants of the aggregate corporate profit margin by using capacity utilization, unit labour cost, inflation and exports. The authors examined whether a rise in unit labour cost, defined as the ratio of wages per hour over productivity, is associated with a fall in the profit margin. Their empirical findings attested to a clear negative association between unit labour costs and profit margins. This finding is corroborated by the stylized facts presented in the study by Bottazi et al. (1996) who used a sample of OECD countries and showed that the average correlation between the profit and wage rates is negative for all but four countries (which include the US). Alesina et al. (2002) examined the effects of various fiscal variables on profits, proxied by gross profits per unit of capital in the business sector. They found that all revenues and spending variables exert a negative impact on profits with government wages having the largest negative effect (mostly through their influence on private sector wage outcomes) .

Our central aim is to analyze how net return on capital for the total economy is affected by wage changes that do not reflect changes in productivity. The estimated equation has the following form:

$$
n r k_{i, t}=\beta_{0}+\beta_{1} e_{i, t}+\beta_{2} n r k_{i, t-1}+\beta_{3} \mathbf{Z}_{i, t}+\mu_{i}+\lambda_{t}+\varepsilon_{i, t}
$$

where $n r k_{i, t}$ and $e w_{i, t}$ denote profits and excessive wages in country $i$ at period $t$ respectively. In turn, the parameter $\beta_{1}$ measures the causal impact of excessive wages on capital return. The lagged value of capital return on the right hand side is included to capture potentially mean-reverting dynamics triggered by longrun economic cycles and also the well-known persistence in profits (see, for instance, Geroski and Jacquemin, 1988; Mueller, 1990; Goddard and Wilson, 1999; McGahan and Porter, 1999; Glen et al., 2001). The terms $\mu_{i}$ and $\lambda_{t}$ allow for country dummies and time-specific effects respectively, and $\varepsilon_{i, t}$ is the error term with $E\left(\varepsilon_{i, t}\right)=0$ for all $i$ and $t$. The vector $\mathbf{Z}_{i, t}$ is a set of exogenous variables that control for

\footnotetext{
${ }^{9}$ There is however a relatively larger literature that has attempted to identify the determinants of profits at the sectoral level using measures of the market value or accounting profits (e.g., Schmalensee, 1989; McGahan and Porter, 2002). The determinants include firm-specific characteristics, like market share, market share growth, productivity, firm concentration ratio, replacement value capital stock and growth of the firm, as well as market structure and industry-specific characteristics, like barriers to entry, stock of advertising, stock of research and development, and efficient-size measures.
} 
profits-related characteristics and includes the initial value of the per capita output growth rate as a measure of aggregate domestic demand, the real interest rate as a measure of the cost of capital, the average level of schooling of the population as a measure of technology in the economy, and the share of government capital expenditures in total government expenditures that increases aggregate productivity and capital return through the positive impact of productive infrastructure for economic activity.

Regarding the construction of an indicator for unwarranted wage changes, one may well think that such a measure is provided by the "unit labour cost" variable calculated by the OECD. However, as argued by Feldstein (2008), wages have not risen as rapidly as total compensation because of the rise in fringe benefits and other non-cash payments. Thus, we need to compare the productivity rise with the increase of total compensation rather than with the increase of the narrower measure of just wages and salaries. Along this line, and following Malley and Moutos (2006), we obtain excessive wages by estimating the following regression for each country using annual data over the period 1970-2000:

$$
\ln W_{t}=\alpha_{0}+\alpha_{1} \ln P_{t}+u_{t}
$$

where $W_{t}$ is the real total compensation per employee and $P_{t}$ is the productivity index. The residuals, $u_{t}$, are defined as excessive wages, $e w_{t}$, applied in the estimated regressions.

\subsection{Data}

Based on data availability, we use a panel of 19 OECD countries to estimate equations over the period 1970-2000. ${ }^{10}$ We follow the standard approach of constructing 5-year period averages so as to minimize business cycle effects and the well-known procyclicality of profits and wages (see Bottazzi et al., 1996). ${ }^{11}$ The detailed presentation of the dataset can be found in the Data Appendix of the paper.

Our first concern is to choose an appropriate capital return indicator for our dependent variable. The

\footnotetext{
${ }^{10}$ The countries included are Australia, Austria, Belgium, Canada, Denmark, Finland, France, Germany, Ireland, Italy, Japan, Netherlands, Norway, Portugal, Spain, Sweden, Switzerland, United Kingdom, United States.

${ }^{11}$ We have experimented with averaging the data over shorter subperiods (3-year periods), obtaining qualitatively similar results with 5-year averaged data.
} 
two main sources of profit data are national account and corporate account data. We use here national account data since they cover the whole economy and are more consistent across countries and time. Generally, the measurement of profits and capital return at the macroeconomic level is subject to a high degree of uncertainty. The measurement of the net rate of return on capital is affected by all the difficulties related to the calculation of the capital stock. On the other hand, the measurement of profits may contain distortions associated with the difficulties in measuring other economic variables since profits are in general calculated as a residual. The gross operating surplus is the national account measure of profits but it is not net of corporate income tax or interest payments. Its definition on a net (of depreciation) basis may be more meaningful economically, but its calculation faces the difficulty of defining the depreciation rate across countries, across sectors of activity and across time. We attempt to minimize this uncertainty by considering several capital return (or profit) indicators. We use three alternative indicators of profit development as our dependent variable, all obtained by AMECO database (European Commission, Economic and Financial Affairs Indicators), namely the net return on net capital stock, $n r k$, the gross operating surplus as a share of GDP, gpr/y, and the net (of depreciation) operating surplus as a share of GDP, $n p r / y{ }^{12}$ We relate profits either to output or to capital stock since absolute measures of profits reflect mainly the size of the economy.

In our basic regressions we measure excessive wages by using real total compensation per employee, defined as compensation per employee deflated by GDP deflator, over the OECD productivity index. Notice that productivity is measured in terms of hours worked, rather than employment, and hence it captures variations in both the extensive and the intensive margin of labour utilization. Variations along the intensive margin (i.e. hours of work) of labour utilization have important consequences for the movement of both hourly productivity and hourly real wages during the business cycle. For example, during a downturn firms (constrained by workers' reservation utilities) may be willing to increase the hourly wage rate in order to contain the reduction in workers' take-home pay which results from the

\footnotetext{
${ }^{12}$ For an extensive discussion about the advantages and shortcomings of our three profits variables see ECB Monthly Bulletin (2004). Note that $n r k$ is not available for Switzerland.
} 
decline in hours of work (Bernanke, 1986). Work intensity also varies during the business cycle; during downturns there is an increased excess of total paid-for to actual effective hours worked which impacts adversely on measured productivity (Darby and Hart, 2008). Our use of five-year averages should minimize the influence of these effects.

As a final step, we specify the set of control variables, $\mathbf{Z}$, which will be included in equation (1). We obtain the growth rate of output per capita, gypc, and government capital expenditure as a ratio of total government expenditure, gcap/g, from World Bank, World Development Indicators. The real interest rate, rir is obtained from the Baker at al. (2004) dataset that draws from IMF data. ${ }^{13}$ Variable educ stands for average years of schooling taken from a dataset collected by Barro and Lee (2000) and interpolated by Nickell (2006).

\section{Empirical results}

In this section we initially present evidence from estimated regressions under the central assumption that excessive wages are exogenous to the return on capital. We then address the potential endogeneity of excessive wages by conducting panel estimations based on instrumental variable (IV) techniques.

\subsection{Baseline results}

Our baseline results from estimating equation (1) are reported in Table 1. As stated above, we estimate our model using three different profit indicators as our dependent variable. The net rate of return on capital is the dependent variable in columns (1)-(3), gross profits as a share of GDP is the dependent variable in columns (4)-(6) and net profits to GDP ratio is the dependent variable in columns (7)-(9).

Specifically, columns (1), (4) and (7) report the results of the OLS estimation of equation (1) when only the 'core' control variables, namely the demand indicator and the capital cost are included in the profit equation. In order avoid the potential endogeneity of per capita income growth we use its initial value, which may plausibly be taken as exogenous to the subsequent five years of the capital return and

\footnotetext{
${ }^{13}$ This dataset was created by the IMF and was used for the fourth chapter of April 2003 World Economic Outlook 'Unemployment and labour market institutions: Why reforms pay off'.
} 
profits. As can be readily seen, independently from the profit indicator used, excessive wages, ew, are negative and statistically significant providing clear evidence for a negative impact of $e w$ on profits. Also, in all cases the control variables have the expected sign. Specifically, output growth per capita, gypc, has a positive effect on the profit share while the real interest, rir, enters with a positive but statistically insignificant coefficient.

In columns (2), (4) and (8) we repeat the same exercise after including the average level of schooling, $e d u c$ and the lagged government capital expenditure ratio, gcap/g, in our estimated specification. The coefficient of $e d u c$ is statistically significant at the $10 \%$ level in column (5) indicating that a rise in the educational level of the working population has a positive impact on profits. The impact of $g$ cap/g on the gross and net profit-to-GDP ratio is also positive and statistically significant while gcap/g does not seem to exert a significant impact on the net rate of return on capital. Thus, our results support partly the argument that shifting government expenditure towards its more 'productive' component, namely capital expenditure, may have a positive impact on aggregate productivity and profits.

Finally, in columns (3), (6) and (9) we estimate the dynamic form of equation (1) by performing the Arellano and Bond (1991) methodology for dynamic panel data estimation to account for the impact of lagged profits on current profits. In all cases the coefficient on the lagged dependent variable is statistically insignificant. The impact of excessive wages on profits retains its statistical significance, whereas the coefficient on gypc is found to be statistically significant at the $10 \%$ statistical significance level only in the case where the net return on capital is the dependent variable. The coefficient of real interest reported in column (3) is negative and statistically significant, indicating that a rise in cost of capital will have a negative effect on the net rate of return on capital. The government capital expenditure ratio is positive and statistical significant in all three cases although its statistical significance level is lower in columns (6) and (9). Finally, the coefficient of the average schooling level is positive and statistically significant at the $10 \%$ statistical significance level in columns (3) and (6). For these specifications, we also report the Arellano-Bond test for serial correlation, the existence of which can cause a bias to both the estimated coefficients and standard errors. The $p$-values of the AR(2) test do not 
indicate the presence of serial correlation.

To sum up, our results indicate that excessive wages, proxied by the part of wage growth that cannot be explained by changes in productivity, have a negative impact on profits. This result is robust to the definitions of profits, the variables included in the estimated specification and the estimation procedure. In the next section we investigate how the assumption of exogeneity of excessive wages affects our results.

\subsection{Addressing the endogeneity of excessive wages}

The negative impact of unwarranted wages on capital return, established in the previous subsection, can be challenged by the endogeneity of unwarranted wages. While we do not have an ideal source of exogenous variation to estimate any causal effects of unwarranted wages on capital return, there are some promising potential instruments and we experiment with several instrument sets to account for the robustness of the results. The identification restriction is that $\operatorname{Cov}\left(\right.$ instrument $\left._{i, t}, \varepsilon_{i, t} \mid \mathbf{Z}_{i, t}, \mu_{i}, \lambda_{t},\right)=0$, where instrument denotes the instrumental variables used in the first-stage regression. Below we present the instrument sets along with empirical evidence.

One main instrument related to unwarranted wage changes is the degree of wage bargaining centralization. It is well known (see e.g. Layard et al., 1991) that labour markets in the United States and Canada have the distinctive feature of overlapping, long-term wage agreements, which are only partially indexed, whereas other economies have some combination of short-term contracts, high indexation, or centralized bargaining. The stylized facts regarding the centralization (or coordination) of wage bargaining are that in Anglo-Saxon countries there is no coordination of wage bargaining, whereas in the Nordic countries and Austria there is a high degree of explicit coordination, with the rest of the countries falling in between these extremes (OECD, 1997). ${ }^{14}$ In the Nordic countries (e.g. Sweden), the high degree of coordination took the form of gearing wage policy towards maintaining the productivity of the sector exposed to international competition, with economy-wide wage increases tied to productivity growth in

\footnotetext{
${ }^{14}$ For instance, the IG METALL in Germany provides implicit coordination, whereas in Japan during the "spring offensive" the unions communicate their wage targets, which become the focal point of individual wage bargains.
} 
the traded sector. To the extent that productivity growth in the non-traded (service) sector was lagging behind compared to the traded sector and that the wage growth differential between the two sectors did not match the differential productivity growth, this may well show up as an unwarranted wage increase at the macroeconomic level. On the other hand, Calmfors and Drifill (1988) have argued that centralized bargaining leads to an internalization of the price-level externality present when bargaining takes place at the industry level, thus constraining the appearance of unwarranted wage changes. ${ }^{15}$

We proxy the level of wage bargaining centralization, $c w b$, by an index of bargaining coordination taken from Ochel (2000) and interpolated by Nickell (2006), which has a range $\{1,3\}$ and is increasing with the level of coordination. Table 2 presents the results when $c w b$ is used as an instrument for excessive wages. The lower panel of Table 2 reports first-stage regressions for excessive wages with or without lagged profits (the first-stage regression is common for specifications (1) to (3)). The corresponding first-stage regression for excessive wages, ew, in specifications (4) to (6) include $c w b$, the lagged value of profits, the vector $\mathbf{Z}$, and the country dummies and time effects. The coefficient on $c w b$ has the expected negative sign and is statistically significant in all first-stage regressions. The upper panel of Table 2 reports the results from the second stage where $c w b$ is used as an instrument for $e w$. The coefficient of excessive wages is found to be statistically insignificant in all cases, which implies that taking into account the endogeneity of excessive wages eliminates their impact on profits. The rest of the variables retain their signs and significance levels.

Alternatively, we include the level of minimum wage/median wage as an instrument along with wage bargaining centralization. In a profit-maximizing framework a rise in the minimum wage raises labour costs and reduces profits. However, the fall in profits depends on the extent to which other decisions by firms, like reductions in non-wage benefits or shifts in the mix of factor inputs away from minimum wage labour, offset the rise in the minimum wage (Neumark and Wascher, 2008). Card and Krueger (1995) have shown that in efficiency wage models, in which firms choose both the employment and the wage

\footnotetext{
${ }^{15}$ Eichengreen (1996) argues that centralization and coordination of sectoral wage negotiations in post-War II Europe were a key institutional feature of its growth success by moderating wage claims and thus inducing a rise in profits and investment.
} 
rate, a rise in excessive wages brought about by a rise in the minimum wage can leave profits unchanged, as cost-saving behaviour may induce a movement towards the production frontier that can offset the increased labour costs. Some microeconomic studies have examined either the effect that minimum wages or the formation of trade unions may have on profitability.

In Table 3 we add as an instrument the minimum wage as a percentage of the median wage, minw, taken from OECD Labour Market Statistics database. Including minw decreases our sample since the variable is available only for ten of our sample countries. Specifically, minw does not exist for Austria, Denmark, Finland, Germany, Ireland, Italy, Norway, Sweden and Switzerland. Although the coefficient of minw is statistically insignificant, including $\min w$ increases the significance of $c w b$. The results from the second stage indicate that the coefficient of excessive wages on profits is again statistically insignificant when either the net return of capital or the net profits to GDP ratio are used as the dependent variable. The picture is somewhat less clear when the gross profits to GDP ratio is used as a measure of profits, although the coefficient turns out again insignificant (but only marginally when the lagged dependent variable is included).

As a next step, we also attempt to capture the relationship between unwarranted wages and labour force characteristics related to unionization and the structure of the labour force by using the share of employees in the service sector along with wage bargaining centralization. On the one hand, employees in services tend to be less unionized than employees in industry implying that their share in total employment may be negatively correlated with unwarranted wages. On the other hand, this share may also have a positive impact on ew according to the standard Balassa-Samuelson effect, since higher productivity growth in the traded sector may result in unwarranted wage growth in the non-traded sector.

To account for these channels we obtain the share of employees in services in total employees, servemp, from OECD Employment by Activities and Status dataset, which is a subset of the Annual Labour Force Statistics database. Table 4 presents the results when $c w b$ is included jointly with servemp in the instrument list and confirms the broad picture derived earlier on. The results show that servemp has a negative but only marginally statistically significant impact on excessive wages. In fact, the first-stage 
regressions of Table 4 indicate that $c w b$ and servemp do not identify excessive wages as well as $c w b$ and minw. In the presence of such weak identification, the bias in the second stage can be substantial even if only a weak relationship exists between servemp and the residuals in the capital return equation. In spite of these issues, the results from the second stage reported at the upper half of Table 4 indicate that the impact of excessive wages on capital return disappears when either the net return of capital or the net profits to GDP ratio are used as dependent variable; However, in the case of gross profits to GDP ratio the coefficient on ew turns out significant.

Finally, we explore the endogeneity of $e w$ by using another set of instruments, which aims at addressing the employment characteristics and involves the age structure of the labour force and the rate of occupational injuries. Human capital theory suggests that even for competitive firms the payment for labour services need not be matched contemporaneously with their delivery. Becker's (1964) distinction between general training (which increases the employee's productivity irrespectively of the firm he works for) and specific training (which enhances the productivity of employees only within the firm providing it) implies that depending on the form of training provided, the workers may not, at any particular period of their life, be paid their marginal product. For example, if we examine young workers, it is only those receiving specific training that can be expected to earn their current marginal product (as the firm would have to pay them their opportunity cost in order to retain them); by the same token, if we look at older workers, it is only those that have received general training that can be expected to earn their current marginal product (Hutchens, 1989). Similarly, Lazear's (1979) incentive-compatible model of wage growth is predicting an age-earnings profile that is steeper than the evolution of worker productivity. Hellerstein et al. (1999) find that older workers (aged 55 and over) are receiving a wage premium that exceeds any estimated productivity differential (which is, in fact, sometimes significantly negative) relative to younger workers. They also find that prime-aged (35-54) workers are equally productive to their younger counterparts, but their pay is higher. These results suggest that the age-related composition of the workforce may be an important determinant of unwarranted wage changes. In turn, occupational injuries reflect the safety of the workplace environment, and their lack of occurrence may be thought of as 
a compensating wage differential. We expect the rate of occupational injuries to be correlated with unwarranted wages since workers will be willing to accept a risky job only if they are compensated by higher wages. We note that with regard to the excludability of the instruments, while there is no precise theory for why occupational injuries should affect capital return, it seems natural to expect that changes in occupational injuries over periods of five years should have no direct effects on the sources of business profits measure either in the form of gross or net profits, or as the net return on capital.

The rate of occupational injuries as a ratio of total labour force, occinj, is obtained by the OECD Social Expenditure database and the share of the labour force aged 55-65 in total employment, lfratio, is obtained from OECD Labour Force Statistics by Sex and Age dataset which is a subset of the Labour Force Statistics database. Table 5 reports regressions where occinj and lfratio are used to instrument out $e w$. The coefficients of occinj and lfratio in the first-stage regression for excessive wages are statistically significant in all cases confirming that a rise in occupational injuries and the share of the labour force aged 55-65 are associated with higher excessive wages and reinforce the view implies that occinj and lfratio are valid instruments for $e w$. Again, the results from the second stage show that the coefficient of excessive wages is found to be statistically insignificant in all cases.

\section{Sensitivity analysis}

Our general findings indicate that taking into account the endogeneity of unwarranted wages eliminates their impact on profits. In order to test the robustness of our results to alterations in the chosen measures and samples we conduct a battery of sensitivity robustness tests. To save space we report here only the main tests and the main results; the detailed results are available upon request.

We first exclude all observations with estimated errors in the upper and lower 5 percentile of the distribution. Excluding outliers results in a statistically significant coefficient of excessive wages on profits in columns (2) and (5) of Table 3 and in columns (3) and (6) of Tables 5 . All our previous results remain valid.

As a further robustness test we want to check whether our results depend on our definition of 
unwarranted wages. To that purpose we re-estimate our model using alternative definitions of $e w$ in order to test whether our results depend, firstly, on the fact that we define unwarranted wages as the product of an estimation process and, secondly, on the specific form of the equation from which ew is derived. We use as a measure of excessive wages two alternative variables that are not the outcome of an estimation process. The first one is the standard unit labour cost measure, calculated as the ratio between labour compensation per labour input (per hour or per employee) and labour productivity. Alternatively, we use the ratio of real compensation of employee deflated by the private consumption price index to labour productivity (both variables are taken from OECD, Economic Outlook database). Estimating all equations depicted in Tables 1-5 using any of these measures for unwarranted wages does not affect our main results.

We also estimate equation (2) using alternative definitions of $W_{t}$ (the real total compensation per employee) and $P_{t}$ (the index of productivity). Specifically, we use the labour compensation per unit labour input and the labour compensation per employee as alternative measures of $W_{t}$ and labour productivity per unit labour input and labour productivity per employee as alternative measures of $P_{t}$ (all variables are taken from OECD, Economic Outlook database).

One can further argue that productivity will affect wages with a lag (e.g. due to the existence of longterm contacts, or delays in recognizing the precise magnitude of productivity changes). Therefore, we reestimate these two new versions of equation (2) as well as the initial one by assuming that $W_{t}$ depends on lagged productivity $P_{t-1}$ instead of the current productivity level. The residual series of these five new versions of equation (2) can be used as alternative estimates of excessive wages. After having re-estimated all equations in Tables 1-5 using these alternative definitions of unwarranted wages we find that our main results remain unaffected.

Although our estimates of excessive wages are derived on a country-by-country basis using equation (2), they might also contain country and time fixed effects. ${ }^{16}$ To control for these effects we pool equation (2) and we now obtain excessive wages by estimating the following regression for each country

\footnotetext{
${ }^{16}$ We wish to thank Bob Hart for alerting us to this possibility.
} 


$$
\ln W_{i, t}=\gamma_{0}+\gamma_{1} \ln P_{i, t}+\psi_{i}+\zeta_{t}+v_{i, t}
$$

where $\psi_{i}$ and $\zeta_{t}$ allow for country dummies and time-specific effects respectively, and $v_{i, t}$ is the error term with $E\left(v_{i, t}\right)=0$ for all $i$ and $t$. Defining excessive wages, $e w_{i, t}$ as the residuals $v_{i, t}$ from equation (2)' and re-estimating the equations presented in Tables 1-5 does not affect our main results.

Finally, Blanchard (1997) has argued that OECD countries can be placed in two groups with respect to the behaviour of the labour share. In the first group belong the Anglo-Saxon countries (Canada, UK, and USA), where the labour share remained largely unchanged during the last three decades of the twentieth century. In the other group of countries, consisting mostly of the continental European economies, there is an inverted U-shaped pattern for the labour share (high in the early 1980s and lower towards the end of the century). The differential movements in the labour share may be related to differences in collective bargaining coverage and perceived union/political strength of the labour movement across countries (see, OECD, 1997). According to some studies (e.g. Caballero and Hammour, 1998a, 1998b; Nickell et al., 2005), the relatively strong trade unions in the continent managed to resist the moderation in wage growth that was warranted by the slowdown in productivity growth, thus inducing firms to redirect new investment abroad and/or to the adoption of less labour-intensive technologies. The resulting shortfalls in labour demand led to a rise in unemployment, which weakened the outside option of labour in the employment relationship and caused a terms-of-trade shift that helped restore equilibrium by raising the return on capital back to the level required by international markets.

To address the potentially differential patterns of wages and profits in these countries we perform the analysis presented in Tables 2, 4 and 5 after excluding US, UK and Canada from our sample. ${ }^{17}$ The results are summarized in Table 6. It should be noted that excluding US, UK and Canada implies that wage bargaining centralization together with the share of employees in services in total employment can no longer be considered appropriate instruments for excessive wages, as indicated by the corresponding F-

\footnotetext{
${ }^{17}$ We refrain from using the minimum wage as a percentage of the median wage, minw, as an additional instrument since doing this would reduce our sample to only 7 countries.
} 
test ${ }^{18}$. Yet, as can be readily seen the main picture remains quite robust to the exclusion of the AngloSaxon countries. When wage bargaining centralization is used as an instrument for excessive wages the results (shown in the upper part of Table 6) are quite similar to those presented in Table 2. The same holds when the rate of occupational injuries as a ratio of total labour force and the share of the labour force aged 55-65 in total employment are used as instruments for excessive wages. Comparing the results shown in the lower part of Table 6 to those of Table 5, the impact of excessive wages on capital return and profits disappears in all cases.

\section{Conclusions}

This paper investigated the effect of unwarranted wage changes, defined as wage changes which can not be accounted by changes in labour productivity, on capital return. Although, a cursory look at the data reveals a negative association between the two variables, we find that taking into account the endogeneity of unwarranted wage changes with respect to the return on capital and profits shows that there is no causal relationship between the two variables.

Are our results at odds with the standard policy prescriptions, which seem to imply that unwarranted wage changes are detrimental to profitability? Our analysis shows that such a simple-minded inference is flawed, and that such policy prescriptions have to be assessed in the context of more fully articulated models, which allow for the underlying driving factors of unwarranted wage changes. For example, an observation of wages rising faster than labour productivity may induce some policy makers to propose measures intended to reverse this rise in excessive wages (e.g., to propose reductions in minimum wages); our results demonstrate that this would be a wrong policy action if, for example, what would appear as unwarranted wage changes was the result of (privately efficient) rent-sharing mechanisms.

\footnotetext{
${ }^{18}$ Many economists have attributed the "employment gap" between the continental European countries and the Anglo-Saxon countries to the superior expansion of service-sector employment in the latter group of countries (e.g., European Commission, 2002). The slow expansion of the service sector in the continent, along with the fact that nonunionized service-sector workers are covered through extension-laws by collective bargaining agreements are possible explanations for why the moderate changes in service-sector employment are not found to be important determinants of excessive wage changes.
} 


\section{APPENDIX}

\section{Excessive wages and their co-movement with profits: An example}

In the Appendix we present a simple illustration of the possibility that changes in some "deep" parameters relating to the labour market can induce positive co-movements of excessive wages and the return on capital.

Consider a perfectly competitive firm run by an entrepreneur, which is the residual claimant of what is left (profits) after paying for the use of factor services (capital, $K$, and labour, $L$ ). We assume that the firm does not act as if facing a perfectly elastic labour supply schedule, and that it manipulates the wage offered to its employees in order to maximize its profits (or equivalently, to minimize the cost per efficiency unit of labour). The production function takes a CES form given by:

$$
Q=\left[(e L)^{\rho}+K^{\rho}\right]^{\alpha / \rho}
$$

where $Q$ denotes output, $e$ stands for the efficiency (or effort) of each unit of labour, $\rho \leq 1$, determines the size of the elasticity of substitution between labour and capital, $\sigma \equiv 1 /(1-\rho)$, and $\alpha<1$ implies decreasing returns to scale.

A convenient specification of the effort function assumes that productivity (effort) does not depend on the level of the wage offered by the firm, but rather on the relative attractiveness of wages offered inside and outside the firm. A particular parameterization of this concept is due to Summers (1988) and takes the form:

$$
e=\left(\frac{w-b}{b}\right)^{\theta}, \theta>0
$$

where $w$ is the wage paid by the firm and $b$ summarizes the outside-wage opportunities.

The perfectly competitive firm, in addition to the levels of $K$ (whose rental cost is $r$ ) and $L$, also sets the wage rate so as to maximize profits, $\Pi$, which are equal to:

$$
\Pi=\left[\left(\frac{w-b}{b}\right)^{\rho \theta} L^{\rho}+K^{\rho}\right]^{\alpha / \rho}-w L-r K
$$

The first-order conditions yield the optimal ("efficiency") wage chosen by the firm, $w^{*}$ :

$$
w^{*}=\frac{b}{1-\theta}
$$


As is standard in efficiency wage models, equation (A.4) implies that the efficiency wage set by the firm is a mark-up on the level of the alternative opportunities available to the workers. (If $\theta=0$, the firm pays the competitive wage rate.)

Combining (A.2) and (A.4) we get that the optimal level of effort, $e^{*}$, is given by:

$$
e^{*}=\left(\frac{\theta}{1-\theta}\right)^{\theta}
$$

We note from equations (A.4) and (A.5) that the optimal wage rate and the resulting optimal level of effort depend only on $b$ and $\theta$ (which are exogenous from the firm's point of view). After some manipulations we can obtain the optimal levels for labour and capital, $L^{*}$ and $K^{*}$, as:

$$
\begin{aligned}
& L^{*}=\alpha^{-\left(\frac{1}{\alpha-1}\right)} w^{\frac{1}{\rho-1}} e^{-\left(\frac{\rho}{\rho-1}\right)} \Delta^{\frac{1}{\rho}\left(\frac{\rho-\alpha}{\alpha-1}\right)} \\
& K^{*}=\alpha^{-\left(\frac{1}{\alpha-1}\right)} r^{\frac{1}{\rho-1}} \Delta^{\frac{1}{\rho}\left(\frac{\rho-\alpha}{\alpha-1}\right)}
\end{aligned}
$$

where, $\Delta \equiv w^{\frac{\rho}{\rho-1}} e^{-\left(\frac{\rho}{\rho-1}\right)}+r^{\frac{\rho}{\rho-1}}=\left(\frac{b}{1-\theta}\right)^{\frac{\rho}{\rho-1}}\left(\frac{\theta}{1-\theta}\right)^{\frac{-\rho \theta}{\rho-1}}+r^{\frac{\rho}{\rho-1}}$.

The profit-maximizing level of output, $Q^{*}$, can be calculated by substituting equations (A.6), and (A.7) into (A.1). Substituting $L^{*}, K^{*}$ and $Q^{*}$ in the profit equation (A.3), we get that:

$$
\Pi^{*}=\alpha^{-\left(\frac{1}{\alpha-1}\right)}(1-\alpha) \Delta^{\frac{\alpha}{\rho\left(\frac{\rho-1}{\alpha-1}\right)}}
$$

We are interested in finding how changes in $\theta$ affect both the development of wages $\left(w^{*}\right)$ relative to labour productivity, $y \equiv \frac{Q^{*}}{L^{*}}$, and the return on capital. The "excessive wage", $w_{e x c}$, is defined as the ratio of wages to labour productivity and the return on capital, $r_{K}$, is defined as the sum of capital costs plus “entrepreneurial" profits, $\Pi^{*}$, divided by the capital stock: ${ }^{19}$

$$
\begin{aligned}
& w_{e x c} \equiv \frac{w^{*}}{y^{*}}=\frac{w^{*} L^{*}}{Q^{*}} \\
& r_{K} \equiv \frac{r K^{*}+\Pi^{*}}{K^{*}}=r+\frac{\Pi^{*}}{K^{*}}
\end{aligned}
$$

Given these definitions, it is straightforward to show the following Result.

\footnotetext{
${ }^{19}$ Our definition of excessive wages is identical to the labour share in this model. However, in actual economies the data for the labour share are also shaped by the existence of self-employed individuals and of the public sector.
} 
Result A1. A change in the elasticity of effort with respect to the relative wage differential, $\theta$, causes excessive wages and the return on capital to move in the same direction.

By equations (A.6)-(A.8) we get that:

$$
\begin{aligned}
& \frac{\Pi^{*}}{K^{*}}=r^{-\left(\frac{1}{\rho-1}\right)}(1-\alpha) \Delta \\
& \frac{w^{*} L^{*}}{Q^{*}}=\alpha^{-1}\left(\frac{r^{\frac{\rho}{\rho-1}}}{w^{*\left(\frac{\rho}{\rho-1}\right)} e^{*\left(\frac{-\rho}{\rho-1}\right)}}+1\right)^{-1}
\end{aligned}
$$

We note from the definition of $\Delta$, that the effect of changes in $\theta$ on $\Delta$ are in the same direction as the effects of changes in $\theta$ on $w^{*\left(\frac{\rho}{\rho-1}\right)} e^{\left.* * \frac{-\rho}{\rho-1}\right)}=b^{\frac{\rho}{\rho-1}}(1-\theta)^{\frac{\rho(\theta-1)}{\rho-1}} \theta^{\frac{-\theta \rho}{\rho-1}}$. Thus, any change in $\theta$ will, by inspection of equations (A.9) and (A.10), cause changes in the return on capital and in the ratio of wages and productivity in the same direction (i.e., both to rise, or both to fall).

The above result is independent of the size of the elasticity of substitution between labour and capital. Nevertheless, the elasticity of substitution, $\sigma$, determines the direction in which both excessive wages and the return on capital change in response to changes in $\theta$. Indeed, we find that

$$
\frac{\partial \ln \left(w^{*\left(\frac{\rho}{\rho-1}\right)} e^{*\left(\frac{-\rho}{\rho-1}\right)}\right)}{\partial \theta}=\frac{\rho}{\rho-1}(\ln (1-\theta)-\ln \theta)
$$

Equation (A.11) makes clear that if the production function is Cobb-Douglas $(\rho=0)$, both excessive wages (and the return on capital) are not affected by changes in $\theta$. In signing the above expression, in addition to $\rho$, the parameter value that is of particular interest to us is $\theta$, the elasticity of effort with respect to the "relative wage differential". Summers (1988) notes that even very small values of this parameter can generate sizeable unemployment rates, and suggests that values close to 0.04 are reasonable values for this parameter. Assuming that $\theta<0.5$, implies that $\ln (1-\theta)-\ln \theta>0$ and, thus the sign of (A.11) depends on the elasticity of substitution. If, $\rho>0$, the elasticity of substitution is larger than unity, and in this case both excessive wages and the return on capital will fall in response to a rise in $\theta$. 


\section{References}

Alesina, A., S. Ardagna, R. Perotti and F. Schiantarelli (2002): 'Fiscal policy, profits and investment', American Economic Review, 92, 3, 571-589.

Arellano, M. and S. Bond (1991): 'Some tests of specification for panel data: Monte Carlo evidence and an application to employment equations', Review of Economic Studies, 58, 277-97.

Aghion, P. and P. Howitt (1998): Endogenous Growth Theory, MIT Press: Cambridge.

Azariadis, C. (1975): 'Implicit contracts and underemployment equilibria', Journal of Political Economy, $83,6,1183-1202$.

Baily, M.N. (1974): 'Wages and employment under uncertain demand', Review of Economic Studies, 41, $1,37-50$.

Baker, D., A. Glyn, D. Howell and J. Schmitt (2004): 'Unemployment and labour market institutions: The failure of the empirical case for deregulation', ILO Working Paper No 43.

Barro, R.J. and J. Lee (2000): 'International data on educational attainment: Updates and implications', CID Working Paper No. 42.

Bean, C.R. (1994): 'European unemployment: A survey', Journal of Economic Literature, 32, 2, 573-619.

Becker, G.S. (1964): Human Capital: A Theoretical and Empirical Analysis, National Bureau of Economic Research: New York.

Bernanke, B. (1986): 'Employment, hours, and earnings in the Depression: an analysis of eight manufacturing industries', American Economic Review, 76, 82-109.

Blanchard, O.J. (1997): 'The medium run', Brookings Papers on Economic Activity, 2, 89-158.

Blanchard, O.J. and F. Giavazzi (2003): 'Macroeconomic effects of regulation and deregulation in goods and labor markets', Quarterly Journal of Economics, 118, 3, 879-907.

Blanchflower, D.G. and A.J. Oswald (1994): The Wage Curve, The MIT Press, Cambridge.

Blanchflower, D.G., A.J. Oswald and P. Sanfey (1996): 'Wages, profits, and rent-sharing', Quarterly Journal of Economics, 227-251.

Blau, F.D. and L.M. Kahn (1999): 'Institutions and laws in the labor market', in O. Ashenfelter and D. Card (eds.), Handbook of Labor Economics, Volume 3A, North-Holland: Amsterdam.

Blau, F.D. and L.M. Kahn (2000): 'Wage inequality, collective bargaining and relative employment 198594: Evidence from fifteen OECD countries', Review of Economics and Statistics, 82, 4, 564-579.

Booth, A.L. (1995): The Economics of the Trade Union, Cambridge University Press: Cambridge.

Bottazzi, L., P. Pesenti and E. van Wincoop (1996): 'Wages, profits and the international portfolio puzzle', European Economic Review, 40, 219-254.

Bruno, M. (1984): 'Raw materials, profits, and the productivity slowdown', Quarterly Journal of Economics, 99, 1, 1-30.

Bruno, M. and J. Sachs (1985): The Economics of Worldwide Stagflation, Basil Blackwell: Oxford.

Caballero, R. and M. Hammour (1998a): 'The macroeconomics of specificity', Journal of Political Economy, 106, 4, 724-767. 
Caballero, R. and M. Hammour (1998b): 'Jobless growth: Appropriability, factor substitution and unemployment', Carnegie-Rochester Conference Series on Public Policy, 48, 51-94.

Calmfors, L. and J. Driffill (1988): 'Bargaining structure, corporatism and macroeconomic performance', Economic Policy, 6, 12-61.

Card, D. (1996): 'The effect of unions on the structure of wages: A longitudinal analysis', Econometrica, 64, 4, 957-979.

Card, D. and J.E. DiNardo (2002): 'Skill biased technical change and rising wage inequality: Some problems and puzzles", Journal of Labor Economics, 20, 4, 733-783.

Card, D. and A.B. Krueger (1995): Myth and Measurement: The New Economics of the Minimum Wage, Princeton University Press: Princeton NJ.

Christofides, L. N., and A. J. Oswald (1992): "Real wage determination and rent-sharing in collective bargaining agreements", Quarterly Journal of Economics, 107, 985-1002.

Darby, J. and R.A. Hart (2008): 'Wages, productivity, and work intensity in the Great Depression', Southern Economic Journal, 75, 91-103.

ECB Monthly Bulletin (2004): 'Measuring and analyzing profit developments in the Euro area', January.

Eichengreen, B. (1996): 'Institutions and economic growth: Europe after World War II', in N. Crafts and G. Toniolo (eds.), Economic Growth in Europe Since 1945, Cambridge University Press: Cambridge.

European Commission (2002): Employment in Europe 2002, Employment and Social Affairs: Brussels.

Feldstein, M. (2008): 'Did wages reflect growth in productivity?', Journal of Policy Modeling, 30, 591594.

Finkel, S.R. and D.L. Tuttle (1971): 'Determinants of the aggregate profits margin source', Journal of Finance, 26, 5, 1067-1075.

Frank, R. (1984): 'Are workers paid their marginal product?', American Economic Review, 74, 4, 549571.

Geroski, P.A. and A. Jacquemin (1988): 'The persistence of profits: a European comparison', Economic Journal, 98, 375-89.

Glen, J., K. Lee and A. Singh (2001): 'Persistence of profitability and competition in emerging markets', Economics Letters, 72, 247-53.

Goddard, J.A. and J.O.S. Wilson (1999): 'The persistence of profit: a new empirical interpretation', International Journal of Industrial Organization, 17, 663-87.

Hart, R. A. (1992), Working Time and Employment, Routledge: London.

Hellerstein, J.K., D. Neumark and K.R. Troske (1999): 'Wages, productivity, and worker characteristics: Evidence from plant-level production functions and wage equations', Journal of Labor Economics, $17,3,409-446$

Hutchens, R.M. (1989): 'Seniority, wages and productivity: A turbulent decade', Journal of Economic Perspectives, 3, 49-64.

Inglehart, R.F. (1997), Modernization and Postmodernization: Cultural, Economic and Political Change in 43 Societies, Princeton: Princeton University Press. 
Inglehart, R. F. (2008): 'Changing values among western publics from 1970 to 2006', West European Politics, 31, 1-2, 130-146.

Layard, R., S. Nickell, and R. Jackman (1991): Unemployment, Oxford University Press: Oxford.

Lazear, E. P. (1979): 'Why is there mandatory retirement?', Journal of Political Economy, 87, 6, 1261-84.

Machin, S., A. Manning, and S. Woodland (1993): 'Are workers paid their marginal product? Evidence from a low wage labour market', CEP Discussion Paper No 0158.

Malley, J. and T. Moutos (2006): 'Do excessive wage increases raise imports? Theory and evidence', Japan and the World Economy, 18, 2, 194-220.

Matsuyama, K. (2002): 'The rise of mass consumption societies', Journal of Political Economy, 110, 1035-1070.

McGahan, A.M. and M.E. Porter (1999): ‘The persistence of shocks to profitability', Review of Economics and Statistics, 81, 1, 143-53.

McDonald, I.M. and R. M. Solow (1981): 'Wage bargaining and employment', American Economic Review, 71, 5, 896-608.

McGahan, A.M. and M.E. Porter (2002): 'What do we know about variance in accounting profitability?', Management Science, 48, 7, 834-851.

Mueller, D.C. (1990): Dynamics of Company Profits: An International Comparison, Cambridge University Press: Cambridge.

Mumford, K. and S. Dowrick (1994): 'Wage bargaining with endogenous profits, overtime working and heterogeneous labor', Review of Economics and Statistics, 76, 329-336.

Murphy, K., A. Shleifer and R. Vishny (1989): "Industrialization and the Big Push", Journal of Political Economy, 117, 1003-1026.

Neumark, D. and W.L. Wascher (2008): Minimum Wages, MIT Press: Cambridge.

Nickell, S., L. Nunziata and W. Ochel (2005): 'Unemployment in the OECD since the 1960s: What do we know?', Economic Journal, 115, 1-27,

Nickell, W. (2006): 'The CEP - OECD Institutions data set (1960-2004)', Centre for Economic Performance, London School of Economics, Discussion Paper No. 759.

Ochel, W. (2000): Collective Bargaining: Centralization and Coordination, Ifo Institute: Munich.

OECD (1997): Employment Outlook, OECD: Paris.

OECD (2006): Economic Outlook, OECD: Paris.

Pissarides, C. (2000): Equilibrium Unemployment Theory, (2 ${ }^{\text {nd }}$ ed.), MIT Press: Cambridge.

Rodrik, D. (1999): 'Democracies Pay Higher Wages', Quarterly Journal of Economics, 114, 707-738.

Sachs, J.D. (1979): 'Wages, profits, and macroeconomic adjustment: A comparative study', Brookings Papers on Economic Activity, 2, 269-332.

Schmalensee, R. (1989): 'Intra-industry profitability differences in US manufacturing: 1953-1983', Journal of Industrial Economics, 37, 337-357.

Summers, L. (1988): 'Relative wages, efficiency wages, and Keynesian unemployment', American Economic Review, 78, 2, 383-388. 


\section{Data Appendix}

\section{A. Profit variables}

$n r k$ : Net returns on net capital stock defined as net domestic income minus wage income as a ratio of net capital stock (source: AMECO, code: $A P N D K$, APNDK $=[$ UVND $-[$ UWCD $\times($ NETD : NWTD) $]]$ : $[(\mathrm{OKND} \times \mathrm{PIGT}): 10.000]$ where UVND $=$ Net domestic income at current market prices, UWCD $=$ Compensation of employees, NETD $=$ Employment, persons, NWTD $=$ Employees, persons, OKND = Net capital stock at constant prices, PIGT $=$ Price deflator gross fixed capital formation)

gpr/y: gross operating surplus as a share of GDP, defined as GDP less compensation of employees less taxes (minus subsidies) on production over GDP (source: AMECO, code: $U V G D$ ).

$n p r / y$ : net (of depreciation) operating surplus as a share of GDP, defined as gross operating surplus minus consumption of fixed capital (source: AMECO, code: UOND, UOND = UOGD - UKCT where UKCT= consumption of fixed capital) over GDP.

\section{B. Instruments for excessive wages}

$c w b$ : index of bargaining coordination (taken from Ochel (2000) and interpolated by Nickell (2006), code: $\operatorname{cow}($ int)).

minw: minimum wage as percentage of the median wage (source: OECD Labour Market Statistics database, taken from Nickell (2006), code: $\left.m i n w \_m e d\right)$.

servemp: share of employees in services in total employees (source: OECD, Employment by Activities and Status (ALFS) dataset, Annual Labour Force Statistics (ALFS) database, codes: Employees in Services (ISIC rev.2, 6-9) and Employees in all activities (ISIC rev.2)).

occinj: total cases of compensated occupational injuries (source: OECD, Social Expenditure database, code: Reported injuries, total cases (fatal+non-fatal), ISIC-Rev. 3, as a ratio of total labour force (source: OECD, Economic Outlook, code: Labour force).

Ifratio: share of the labour force aged 55-65 in total employment (source: OECD, Labour Force Statistics by Sex and Age, Labour Force Statistics (LFS) database, code: share of employment, 55-65).

\section{Other variables}

$W$ : real total compensation per employee defined as compensation per employee deflated by GDP deflator (source: OECD, Economic Outlook, codes: Compensation per Employee, total economy and Deflator for GDP at Market Prices).

$P$ : productivity index (source: OECD, Economic Outlook, code: Productivity Index).

rir: real interest rate (source: Baker et al. (2004), based on IMF, International Financial Statistics, code: rir).

gypc: per capita output growth rate (source: World Bank, World Development Indicators)

educ: average years of schooling (source: Barro and Lee (2000), interpolated by Nickell (2006), code: educ (int)).

gcap/g: defined as capital expenditures as a share of total government expenditure, (source: World Development Indicators). 
TABLE 1. Profit equation: exogenous excessive wages

\begin{tabular}{|c|c|c|c|c|c|c|c|c|c|}
\hline & \multicolumn{3}{|c|}{ net return on capital } & \multicolumn{3}{|c|}{ gross profits/GDP } & \multicolumn{3}{|c|}{ gross profits/GDP } \\
\hline & $\begin{array}{l}\text { F.E. } \\
(1)\end{array}$ & $\begin{array}{c}\text { F.E. } \\
(2)\end{array}$ & $\begin{array}{c}\text { A-B } \\
\text { (3) }\end{array}$ & $\begin{array}{l}\text { F.E. } \\
\text { (4) }\end{array}$ & $\begin{array}{c}\text { F.E. } \\
(5)\end{array}$ & $\begin{array}{c}\text { A-B } \\
(6)\end{array}$ & $\begin{array}{l}\text { F.E. } \\
\text { (7) }\end{array}$ & $\begin{array}{l}\text { F.E. } \\
(8)\end{array}$ & $\begin{array}{l}\text { A-B } \\
(9)\end{array}$ \\
\hline$(n r k)_{-1}$ & & & $\begin{array}{c}0.050 \\
(0.51)\end{array}$ & & & & & & \\
\hline$(g p r / y)_{-1}$ & & & & & & $\begin{array}{l}0.193 \\
(1.11)\end{array}$ & & & \\
\hline$(n p r / y)_{-1}$ & & & & & & & & & $\begin{array}{c}0.193 \\
(1.11)\end{array}$ \\
\hline$e w$ & $\begin{array}{c}-1.888 \\
(-4.93)\end{array}$ & $\begin{array}{c}-2.127 \\
(-4.63)\end{array}$ & $\begin{array}{c}-2.520 \\
(-6.51)\end{array}$ & $\begin{array}{l}-0.351 \\
(-4.23)\end{array}$ & $\begin{array}{c}-0.454 \\
(-5.23)\end{array}$ & $\begin{array}{c}-0.519 \\
(-6.94)\end{array}$ & $\begin{array}{l}-0.351 \\
(-4.23)\end{array}$ & $\begin{array}{c}-0.454 \\
(-5.23)\end{array}$ & $\begin{array}{c}-0.519 \\
(-6.94)\end{array}$ \\
\hline rir & $\begin{array}{l}0.269 \\
(0.50)\end{array}$ & $\begin{array}{l}-0.135 \\
(-0.25)\end{array}$ & $\begin{array}{c}-1.257 \\
(-2.85)\end{array}$ & $\begin{array}{c}0.123 \\
(1.12)\end{array}$ & $\begin{array}{l}0.061 \\
(0.63)\end{array}$ & $\begin{array}{c}0.100 \\
(1.85)\end{array}$ & $\begin{array}{c}0.123 \\
(1.12)\end{array}$ & $\begin{array}{l}0.061 \\
(0.63)\end{array}$ & $\begin{array}{c}0.100 \\
(1.85)\end{array}$ \\
\hline gypc & $\begin{array}{c}2.012 \\
(3.01)\end{array}$ & $\begin{array}{l}1.562 \\
(2.57)\end{array}$ & $\begin{array}{l}1.087 \\
(1.79)\end{array}$ & $\begin{array}{l}0.364 \\
(2.78)\end{array}$ & $\begin{array}{c}0.199 \\
(1.86)\end{array}$ & $\begin{array}{l}0.131 \\
(1.45)\end{array}$ & $\begin{array}{c}0.364 \\
(2.78)\end{array}$ & $\begin{array}{l}0.199 \\
(1.86)\end{array}$ & $\begin{array}{c}0.131 \\
(1.45)\end{array}$ \\
\hline$e d u c$ & & $\begin{array}{c}4.334 \\
(1.66)\end{array}$ & $\begin{array}{l}5.288 \\
(1.85)\end{array}$ & & $\begin{array}{c}0.681 \\
(1.89)\end{array}$ & $\begin{array}{c}0.938 \\
(1.89)\end{array}$ & & $\begin{array}{l}0.681 \\
(1.89)\end{array}$ & $\begin{array}{c}0.938 \\
(1.89)\end{array}$ \\
\hline$(\text { gcap } / g)_{-1}$ & & $\begin{array}{c}0.924 \\
(1.08) \\
\end{array}$ & $\begin{array}{c}2.192 \\
(2.36)\end{array}$ & & $\begin{array}{l}0.280 \\
(2.56)\end{array}$ & $\begin{array}{l}0.264 \\
(1.75)\end{array}$ & & $\begin{array}{l}0.280 \\
(2.56)\end{array}$ & $\begin{array}{c}0.264 \\
(1.75) \\
\end{array}$ \\
\hline$R^{2}$ & 0.79 & 0.83 & & 0.51 & 0.64 & & 0.51 & 0.64 & \\
\hline $\operatorname{AR}(2)$ & & & 0.15 & & & 0.23 & & & 0.23 \\
\hline Countries (obs.) & $18(98)$ & $18(83)$ & $17(65)$ & $19(100)$ & $19(84)$ & $17(65)$ & $19(100)$ & $19(84)$ & $17(65)$ \\
\hline
\end{tabular}

Notes:

i) F.E. denotes estimation by Fixed Effects OLS and A-B denotes estimation by the Arellano-Bond estimation method. A constant is included in all regressions. $t$-statistics based on robust standard errors are shown in parentheses. AR(2) is the test on secondorder autocorrelation of the residuals.

ii) Due to data availability Germany and Poland are excluded in regressions (3), (6) and (9) and Switzerland is excluded in regressions (1)-(3). 
TABLE 2. Profit equation: IV estimates

(Instrument: centralization of wage bargaining)

\begin{tabular}{|c|c|c|c|c|c|c|}
\hline Dep. variable & $\begin{array}{l}n r k \\
\text { (1) }\end{array}$ & $\begin{array}{c}g p r / y \\
(2) \\
\end{array}$ & $\begin{array}{c}n p r / y \\
(3)\end{array}$ & $\begin{array}{l}n r k \\
(4)\end{array}$ & $\begin{array}{c}g p r / y \\
(5) \\
\end{array}$ & $\begin{array}{c}n p r / y \\
(6)\end{array}$ \\
\hline$(n r k)_{-1}$ & & & & $\begin{array}{c}-0.382 \\
(-1.30)\end{array}$ & & \\
\hline$(g p r / y)_{-1}$ & & & & & $\begin{array}{l}0.037 \\
(0.34)\end{array}$ & \\
\hline$(n p r / y)_{-1}$ & & & & & & $\begin{array}{c}-0.015 \\
(-0.07)\end{array}$ \\
\hline$e w$ & $\begin{array}{l}1.427 \\
(0.73)\end{array}$ & $\begin{array}{r}-0.365 \\
(-1.44)\end{array}$ & $\begin{array}{c}0.116 \\
(0.30)\end{array}$ & $\begin{array}{l}2.159 \\
(0.87)\end{array}$ & $\begin{array}{c}-0.382 \\
(-1.47)\end{array}$ & $\begin{array}{l}0.125 \\
(0.29)\end{array}$ \\
\hline rir & $\begin{array}{c}-0.357 \\
(-0.54)\end{array}$ & $\begin{array}{c}0.056 \\
(0.61)\end{array}$ & $\begin{array}{c}0.104 \\
(0.70)\end{array}$ & $\begin{array}{c}-0.270 \\
(-0.38)\end{array}$ & $\begin{array}{l}0.049 \\
(0.54)\end{array}$ & $\begin{array}{c}0.106 \\
(0.71)\end{array}$ \\
\hline gypc & $\begin{array}{l}1.771 \\
(2.04)\end{array}$ & $\begin{array}{c}0.204 \\
(2.03)\end{array}$ & $\begin{array}{c}0.356 \\
(2.22)\end{array}$ & $\begin{array}{l}1.910 \\
(1.96)\end{array}$ & $\begin{array}{c}0.196 \\
(1.82)\end{array}$ & $\begin{array}{c}0.359 \\
(2.11)\end{array}$ \\
\hline educ & $\begin{array}{l}0.096 \\
(0.02)\end{array}$ & $\begin{array}{l}0.575 \\
(1.14)\end{array}$ & $\begin{array}{l}0.048 \\
(0.05)\end{array}$ & $\begin{array}{c}-2.203 \\
(-0.36)\end{array}$ & $\begin{array}{l}0.608 \\
(1.21)\end{array}$ & $\begin{array}{l}0.026 \\
(0.02)\end{array}$ \\
\hline$(\text { gcap } / g)_{-1}$ & $\begin{array}{c}-0.231 \\
(-0.24)\end{array}$ & $\begin{array}{l}0.251 \\
(1.13) \\
\end{array}$ & $\begin{array}{l}0.264 \\
(1.38)\end{array}$ & $\begin{array}{c}-0.142 \\
(-0.14)\end{array}$ & $\begin{array}{l}0.239 \\
(1.89)\end{array}$ & $\begin{array}{l}0.268 \\
(1.50) \\
\end{array}$ \\
\hline \multicolumn{7}{|c|}{ First-stage regression for excessive wages } \\
\hline$c w b$ & $\begin{array}{l}-2.151 \\
(-2.61)\end{array}$ & & & $\begin{array}{c}-1.918 \\
(-2.30)\end{array}$ & $\begin{array}{c}-2.094 \\
(-2.54)\end{array}$ & $\begin{array}{r}-1.973 \\
(-2.32)\end{array}$ \\
\hline$(n r k)_{-1}$ & & & & $\begin{array}{c}0.056 \\
(1.67)\end{array}$ & & \\
\hline$(g p r / y)_{-1}$ & & & & & $\begin{array}{l}0.056 \\
(0.35)\end{array}$ & \\
\hline$(n p r / y)_{-1}$ & & & & & & $\begin{array}{c}0.136 \\
(0.86)\end{array}$ \\
\hline rir & $\begin{array}{l}0.008 \\
(0.05)\end{array}$ & & & $\begin{array}{c}-0.006 \\
(-0.04)\end{array}$ & $\begin{array}{c}-0.002 \\
(-0.01)\end{array}$ & $\begin{array}{c}-0.016 \\
(-0.10)\end{array}$ \\
\hline gypc & $\begin{array}{l}0.099 \\
(0.57)\end{array}$ & & & $\begin{array}{c}0.068 \\
(0.39)\end{array}$ & $\begin{array}{c}0.085 \\
(0.46)\end{array}$ & $\begin{array}{l}0.065 \\
(0.36)\end{array}$ \\
\hline educ & $\begin{array}{l}1.742 \\
(1.76)\end{array}$ & & & $\begin{array}{l}1.893 \\
(1.83)\end{array}$ & $\begin{array}{l}1.745 \\
(1.72)\end{array}$ & $\begin{array}{l}1.800 \\
(1.71)\end{array}$ \\
\hline$(\text { gcap } / g)_{-1}$ & $\begin{array}{l}0.317 \\
(1.98) \\
\end{array}$ & & & $\begin{array}{l}0.270 \\
(1.64)\end{array}$ & $\begin{array}{r}0.291 \\
(1.78) \\
\end{array}$ & $\begin{array}{r}0.245 \\
(1.52) \\
\end{array}$ \\
\hline First-stage $R^{2}$ & 0.53 & & & 0.55 & 0.53 & 0.53 \\
\hline F-test (p-value) & 0.010 & & & 0.024 & 0.012 & 0.022 \\
\hline Countries (obs.) & $19(84)$ & & & $18(83)$ & $19(84)$ & $19(84)$ \\
\hline
\end{tabular}

Notes:

i) A constant is included in all regressions. $t$-statistics based on robust standard errors are shown in parentheses.

ii) Due to data availability Switzerland is excluded in regression (4). 
TABLE 3. Profit equation: IV estimates (Instruments: centralization of wage bargaining, minimum wages)

\begin{tabular}{|c|c|c|c|c|c|c|}
\hline Dep. variable & $\begin{array}{l}n r k \\
(1)\end{array}$ & $\begin{array}{c}g p r / y \\
(2) \\
\end{array}$ & $\begin{array}{c}n p r / y \\
(3)\end{array}$ & $\begin{array}{l}n r k \\
(4) \\
\end{array}$ & $\begin{array}{c}\text { gprly } \\
(5) \\
\end{array}$ & $\begin{array}{c}n p r / y \\
(6)\end{array}$ \\
\hline$(n r k)_{-1}$ & & & & $\begin{array}{c}-0.322 \\
(-1.47)\end{array}$ & & \\
\hline$(g p r / y)_{-1}$ & & & & & $\begin{array}{l}0.099 \\
(1.09)\end{array}$ & \\
\hline$(n p r / y)_{-1}$ & & & & & & $\begin{array}{c}0.201 \\
(1.37)\end{array}$ \\
\hline ew & $\begin{array}{c}0.785 \\
(0.51)\end{array}$ & $\begin{array}{r}-0.320 \\
(-1.90)\end{array}$ & $\begin{array}{c}0.163 \\
(0.60)\end{array}$ & $\begin{array}{l}1.891 \\
(1.08)\end{array}$ & $\begin{array}{c}-0.358 \\
(-2.17)\end{array}$ & $\begin{array}{c}-0.034 \\
(-0.12)\end{array}$ \\
\hline rir & $\begin{array}{c}-0.260 \\
(-0.30)\end{array}$ & $\begin{array}{c}0.023 \\
(0.32)\end{array}$ & $\begin{array}{l}0.067 \\
(0.55)\end{array}$ & $\begin{array}{c}-0.323 \\
(-0.37)\end{array}$ & $\begin{array}{c}0.022 \\
(0.32)\end{array}$ & $\begin{array}{l}0.086 \\
(0.97)\end{array}$ \\
\hline gypc & $\begin{array}{l}1.045 \\
(0.95)\end{array}$ & $\begin{array}{c}0.088 \\
(0.66)\end{array}$ & $\begin{array}{c}0.271 \\
(1.26)\end{array}$ & $\begin{array}{l}1.419 \\
(1.15)\end{array}$ & $\begin{array}{c}0.067 \\
(0.48)\end{array}$ & $\begin{array}{l}0.223 \\
(1.09)\end{array}$ \\
\hline educ & $\begin{array}{c}-0.952 \\
(-0.12)\end{array}$ & $\begin{array}{c}-0.655 \\
(-1.04)\end{array}$ & $\begin{array}{c}-0.872 \\
(-0.50)\end{array}$ & $\begin{array}{c}0.382 \\
(0.04)\end{array}$ & $\begin{array}{c}-0.745 \\
(-1.14)\end{array}$ & $\begin{array}{c}-0.929 \\
(0.71)\end{array}$ \\
\hline$(\text { gcap } / g)_{-1}$ & $\begin{array}{r}0.251 \\
(0.27) \\
\end{array}$ & $\begin{array}{c}0.429 \\
(4.40) \\
\end{array}$ & $\begin{array}{r}0.461 \\
(2.95) \\
\end{array}$ & $\begin{array}{c}-0.049 \\
(-0.05) \\
\end{array}$ & $\begin{array}{r}0.387 \\
(3.80) \\
\end{array}$ & $\begin{array}{r}0.437 \\
(3.04) \\
\end{array}$ \\
\hline \multicolumn{7}{|c|}{ First-stage regression for excessive wages } \\
\hline$c w b$ & $\begin{array}{r}-3.342 \\
(-3.29)\end{array}$ & & & $\begin{array}{c}-3.273 \\
(-3.06)\end{array}$ & $\begin{array}{c}-3.381 \\
(-3.39)\end{array}$ & $\begin{array}{c}-3.303 \\
(-3.21)\end{array}$ \\
\hline $\min w$ & $\begin{array}{c}-0.170 \\
(-1.52)\end{array}$ & & & $\begin{array}{c}-0.158 \\
(-1.36)\end{array}$ & $\begin{array}{c}-0.228 \\
(-1.38)\end{array}$ & $\begin{array}{c}-0.161 \\
(-0.91)\end{array}$ \\
\hline$(n r k)_{-1}$ & & & & $\begin{array}{c}0.009 \\
(0.25)\end{array}$ & & \\
\hline$(g p r / y)_{-1}$ & & & & & $\begin{array}{r}-0.147 \\
(-0.50)\end{array}$ & \\
\hline$(n p r / y)_{-1}$ & & & & & & $\begin{array}{l}0.021 \\
(0.07)\end{array}$ \\
\hline rir & $\begin{array}{c}-0.171 \\
(-0.10)\end{array}$ & & & $\begin{array}{c}-0.162 \\
(-0.56)\end{array}$ & $\begin{array}{c}-0.197 \\
(-0.64)\end{array}$ & $\begin{array}{c}-0.164 \\
(-0.57)\end{array}$ \\
\hline gypc & $\begin{array}{l}0.031 \\
(0.10)\end{array}$ & & & $\begin{array}{l}0.026 \\
(0.08)\end{array}$ & $\begin{array}{c}0.023 \\
(0.07)\end{array}$ & $\begin{array}{l}0.031 \\
(0.09)\end{array}$ \\
\hline$e d u c$ & $\begin{array}{l}0.248 \\
(0.07)\end{array}$ & & & $\begin{array}{l}0.179 \\
(0.05)\end{array}$ & $\begin{array}{c}0.566 \\
(0.15)\end{array}$ & $\begin{array}{l}0.216 \\
(0.06)\end{array}$ \\
\hline$(g c a p / g)_{-1}$ & $\begin{array}{l}0.409 \\
(2.14) \\
\end{array}$ & & & $\begin{array}{l}0.407 \\
(2.09)\end{array}$ & $\begin{array}{l}0.481 \\
(2.30)\end{array}$ & $\begin{array}{r}0.400 \\
(1.89)\end{array}$ \\
\hline J-statistic & 0.60 & 0.24 & 0.64 & 0.96 & 0.31 & 0.82 \\
\hline First-stage $R^{2}$ & 0.70 & & & 0.70 & 0.70 & 0.70 \\
\hline F-test (p-value) & 0.004 & & & 0.009 & 0.002 & 0.013 \\
\hline Countries (obs.) & $10(40)$ & & & $10(40)$ & $10(40)$ & $10(40)$ \\
\hline
\end{tabular}

Notes: See Table 2. Due to data availability Austria, Denmark, Finland, Germany, Ireland, Italy, Norway, Sweden and Switzerland are excluded in all regressions 
TABLE 4. Profit equation: IV estimates (Instruments: centralization of wage bargaining, ratio of employees in services)

\begin{tabular}{|c|c|c|c|c|c|c|}
\hline Dep. variable & $\begin{array}{l}n r k \\
(1)\end{array}$ & $\begin{array}{c}g p r / y \\
(2) \\
\end{array}$ & $\begin{array}{c}n p r / y \\
(3)\end{array}$ & $\begin{array}{l}n r k \\
(4)\end{array}$ & $\begin{array}{c}\text { gpr/y } \\
(5) \\
\end{array}$ & $\begin{array}{c}n p r / y \\
(6)\end{array}$ \\
\hline$(n r k)_{-1}$ & & & & $\begin{array}{c}-0.270 \\
(-1.38)\end{array}$ & & \\
\hline$(g p r / y)_{-1}$ & & & & & $\begin{array}{l}0.060 \\
(0.44)\end{array}$ & \\
\hline$(n p r / y)_{-1}$ & & & & & & $\begin{array}{l}0.149 \\
(0.73)\end{array}$ \\
\hline$e w$ & $\begin{array}{c}0.453 \\
(0.37)\end{array}$ & $\begin{array}{l}-0.401 \\
(-2.19)\end{array}$ & $\begin{array}{c}-0.321 \\
(-1.49)\end{array}$ & $\begin{array}{l}1.040 \\
(0.69)\end{array}$ & $\begin{array}{c}-0.437 \\
(-2.10)\end{array}$ & $\begin{array}{c}-0.412 \\
(-1.55)\end{array}$ \\
\hline rir & $\begin{array}{c}-0.231 \\
(-0.36)\end{array}$ & $\begin{array}{c}0.080 \\
(0.75)\end{array}$ & $\begin{array}{c}0.158 \\
(1.07)\end{array}$ & $\begin{array}{c}-0.143 \\
(-0.21)\end{array}$ & $\begin{array}{l}0.072 \\
(0.68)\end{array}$ & $\begin{array}{c}0.136 \\
(1.03)\end{array}$ \\
\hline gypc & $\begin{array}{l}1.444 \\
(1.84)\end{array}$ & $\begin{array}{l}0.209 \\
(1.856)\end{array}$ & $\begin{array}{c}0.325 \\
(1.45)\end{array}$ & $\begin{array}{l}1.593 \\
(1.83)\end{array}$ & $\begin{array}{l}0.199 \\
(1.67)\end{array}$ & $\begin{array}{l}0.297 \\
(2.19)\end{array}$ \\
\hline$e d u c$ & $\begin{array}{c}-1.603 \\
(-0.46)\end{array}$ & $\begin{array}{l}0.501 \\
(1.19)\end{array}$ & $\begin{array}{c}0.190 \\
(0.35)\end{array}$ & $\begin{array}{c}-3.201 \\
(-0.71)\end{array}$ & $\begin{array}{l}0.556 \\
(1.30)\end{array}$ & $\begin{array}{l}0.368 \\
(0.64)\end{array}$ \\
\hline$(\text { gcap } / g)_{-1}$ & $\begin{array}{l}0.634 \\
(0.65)\end{array}$ & $\begin{array}{l}0.299 \\
(2.29)\end{array}$ & $\begin{array}{c}0.544 \\
(2.86)\end{array}$ & $\begin{array}{c}0.610 \\
(0.60)\end{array}$ & $\begin{array}{l}0.286 \\
(2.23)\end{array}$ & $\begin{array}{l}0.505 \\
(2.87) \\
\end{array}$ \\
\hline \multicolumn{7}{|c|}{ First-stage regression for excessive wages } \\
\hline$c w b$ & $\begin{array}{c}-2.079 \\
(-2.15)\end{array}$ & & & $\begin{array}{r}-1.945 \\
(-2.02)\end{array}$ & $\begin{array}{r}-2.007 \\
(-2.04)\end{array}$ & $\begin{array}{r}-1.892 \\
(-1.88)\end{array}$ \\
\hline servemp & $\begin{array}{c}-0.446 \\
(-1.93)\end{array}$ & & & $\begin{array}{c}-0.397 \\
(-1.69)\end{array}$ & $\begin{array}{c}-0.431 \\
(-1.74)\end{array}$ & $\begin{array}{c}-0.419 \\
(-1.77)\end{array}$ \\
\hline$(n r k)_{-1}$ & & & & $\begin{array}{l}0.042 \\
(1.18)\end{array}$ & & \\
\hline$(\operatorname{gpr} / y)_{-1}$ & & & & & $\begin{array}{l}0.057 \\
(0.28)\end{array}$ & \\
\hline$(n p r / y)_{-1}$ & & & & & & $\begin{array}{l}0.141 \\
(0.77)\end{array}$ \\
\hline rir & $\begin{array}{l}0.212 \\
(0.83)\end{array}$ & & & $\begin{array}{c}0.173 \\
(0.67)\end{array}$ & $\begin{array}{c}0.198 \\
(0.71)\end{array}$ & $\begin{array}{c}0.180 \\
(0.67)\end{array}$ \\
\hline gypc & $\begin{array}{l}0.110 \\
(0.55)\end{array}$ & & & $\begin{array}{c}0.080 \\
(0.40)\end{array}$ & $\begin{array}{l}0.096 \\
(0.45)\end{array}$ & $\begin{array}{l}0.073 \\
(0.35)\end{array}$ \\
\hline$e d u c$ & $\begin{array}{l}1.626 \\
(1.57)\end{array}$ & & & $\begin{array}{l}1.745 \\
(1.57)\end{array}$ & $\begin{array}{l}1.622 \\
(1.53)\end{array}$ & $\begin{array}{l}1.646 \\
(1.51)\end{array}$ \\
\hline$(\text { gcap } / g)_{-1}$ & $\begin{array}{l}0.400 \\
(2.11) \\
\end{array}$ & & & $\begin{array}{r}0.365 \\
(1.83) \\
\end{array}$ & $\begin{array}{l}0.374 \\
(1.78) \\
\end{array}$ & $\begin{array}{r}0.330 \\
(1.60) \\
\end{array}$ \\
\hline J-statistic & 0.15 & 0.76 & 0.03 & 0.18 & 0.76 & 0.03 \\
\hline rst-stage $R^{2}$ & 0.54 & & & 0.55 & 0.54 & 0.54 \\
\hline F-test (p-value) & 0.008 & & & 0.023 & 0.023 & 0.029 \\
\hline Countries (obs.) & $18(74)$ & & & $18(74)$ & $18(74)$ & $18(74)$ \\
\hline
\end{tabular}

Notes: See Table 2. Due to data availability Switzerland is excluded in all regressions. 
TABLE 5. Profit equation: IV estimates

(Instruments: occupational injuries, labour force 55-65 ratio)

\begin{tabular}{|c|c|c|c|c|c|c|}
\hline Dep. variable & $\begin{array}{l}n r k \\
(1)\end{array}$ & $\begin{array}{c}g p r / y \\
(2)\end{array}$ & $\begin{array}{c}n p r / y \\
(3)\end{array}$ & $\begin{array}{l}n r k \\
(4)\end{array}$ & $\begin{array}{c}\text { gprly } \\
\text { (5) }\end{array}$ & $\begin{array}{c}n p r / y \\
(6)\end{array}$ \\
\hline$(n r k)_{-1}$ & & & & $\begin{array}{l}-0.36 \\
(-0.84)\end{array}$ & & \\
\hline$(g p r / y)_{-1}$ & & & & & $\begin{array}{l}-0.14 \\
(-0.77)\end{array}$ & \\
\hline$(n p r / y)_{-1}$ & & & & & & $\begin{array}{l}-0.04 \\
(-0.16)\end{array}$ \\
\hline ew & $\begin{array}{l}-0.50 \\
(-0.44)\end{array}$ & $\begin{array}{l}-0.13 \\
(-0.88)\end{array}$ & $\begin{array}{l}-0.05 \\
(-0.22)\end{array}$ & $\begin{array}{l}-0.25 \\
(-0.19)\end{array}$ & $\begin{array}{l}-0.13 \\
(-0.86)\end{array}$ & $\begin{array}{l}-0.04 \\
(-0.19)\end{array}$ \\
\hline rir & $\begin{array}{l}0.09 \\
(0.06)\end{array}$ & $\begin{array}{l}-0.02 \\
(-0.10)\end{array}$ & $\begin{array}{c}0.16 \\
(0.51)\end{array}$ & $\begin{array}{c}0.15 \\
(0.09)\end{array}$ & $\begin{array}{l}0.01 \\
(0.03)\end{array}$ & $\begin{array}{l}0.17 \\
(0.55)\end{array}$ \\
\hline gypc & $\begin{array}{l}2.91 \\
(2.84)\end{array}$ & $\begin{array}{c}0.13 \\
(0.94)\end{array}$ & $\begin{array}{c}0.43 \\
(2.43)\end{array}$ & $\begin{array}{c}3.25 \\
(2.84)\end{array}$ & $\begin{array}{c}0.16 \\
(1.07)\end{array}$ & $\begin{array}{c}0.44 \\
(2.31)\end{array}$ \\
\hline educ & $\begin{array}{l}5.02 \\
(0.59)\end{array}$ & $\begin{array}{c}0.45 \\
(0.40)\end{array}$ & $\begin{array}{c}0.32 \\
(0.20)\end{array}$ & $\begin{array}{l}3.57 \\
(0.46)\end{array}$ & $\begin{array}{c}0.19 \\
(0.17)\end{array}$ & $\begin{array}{l}0.23 \\
(0.16)\end{array}$ \\
\hline$(\text { gcap } / g)_{-1}$ & $\begin{array}{r}1.00 \\
(0.71) \\
\end{array}$ & $\begin{array}{c}0.06 \\
(0.36) \\
\end{array}$ & $\begin{array}{c}0.11 \\
(0.45) \\
\end{array}$ & $\begin{array}{c}1.10 \\
(0.46) \\
\end{array}$ & $\begin{array}{l}0.08 \\
(0.45) \\
\end{array}$ & $\begin{array}{c}0.12 \\
(0.48) \\
\end{array}$ \\
\hline \multicolumn{7}{|c|}{ First-stage regression for excessive wages } \\
\hline occinj & $\begin{array}{l}1.783 \\
(2.63)\end{array}$ & & & $\begin{array}{l}1.498 \\
(2.14)\end{array}$ & $\begin{array}{l}2.014 \\
(2.58)\end{array}$ & $\begin{array}{l}1.845 \\
(2.27)\end{array}$ \\
\hline Ifratio & $\begin{array}{l}1.439 \\
(2.10)\end{array}$ & & & $\begin{array}{l}1.597 \\
(2.34)\end{array}$ & $\begin{array}{l}1.364 \\
(2.12)\end{array}$ & $\begin{array}{l}1.406 \\
(2.07)\end{array}$ \\
\hline$(n r k)_{-1}$ & & & & $\begin{array}{c}0.098 \\
(0.14)\end{array}$ & & \\
\hline$(g p r / y)_{-1}$ & & & & & $\begin{array}{c}-0.359 \\
(-1.03)\end{array}$ & \\
\hline$(n p r / y)_{-1}$ & & & & & & $\begin{array}{r}-0.055 \\
(-0.17)\end{array}$ \\
\hline rir & $\begin{array}{c}0.095 \\
(0.20)\end{array}$ & & & $\begin{array}{c}0.017 \\
(0.04)\end{array}$ & $\begin{array}{l}0.213 \\
(0.45)\end{array}$ & $\begin{array}{l}0.127 \\
(0.24)\end{array}$ \\
\hline gypc & $\begin{array}{r}-0.165 \\
(-0.61)\end{array}$ & & & $\begin{array}{c}-0.243 \\
(-0.94)\end{array}$ & $\begin{array}{c}-0.090 \\
(-0.30)\end{array}$ & $\begin{array}{c}-0.152 \\
(-0.52)\end{array}$ \\
\hline educ & $\begin{array}{l}1.263 \\
(0.59)\end{array}$ & & & $\begin{array}{l}1.544 \\
(0.76)\end{array}$ & $\begin{array}{l}0.685 \\
(0.31)\end{array}$ & $\begin{array}{l}1.143 \\
(0.48)\end{array}$ \\
\hline$(\text { gcap } / g)_{-1}$ & $\begin{array}{c}-0.156 \\
(-0.54)\end{array}$ & & & $\begin{array}{c}-0.173 \\
(-0.65) \\
\end{array}$ & $\begin{array}{c}-0.115 \\
(-0.38)\end{array}$ & $\begin{array}{r}-0.147 \\
(-0.49)\end{array}$ \\
\hline J-statistic & 0.73 & 0.22 & 0.75 & 0.96 & 0.29 & 0.75 \\
\hline First-stage $R^{2}$ & 0.62 & & & 0.65 & 0.64 & 0.62 \\
\hline F-test (p-value) & 0.008 & & & 0.028 & 0.013 & 0.014 \\
\hline Countries (obs.) & $16(45)$ & & & $15(44)$ & $16(45)$ & $16(45)$ \\
\hline
\end{tabular}

Note: See Table 2. Due to data availability Austria, Netherlands and US are excluded in all regressions and Switzerland is excluded in regression (4). 
TABLE 6. Profit equations for non-Anglosaxon countries: IV estimates

\begin{tabular}{|c|c|c|c|c|c|c|}
\hline Dep. variable & $\begin{array}{l}n r k \\
(1)\end{array}$ & $\begin{array}{c}\text { gprly } \\
(2) \\
\end{array}$ & $\begin{array}{c}n p r / y \\
\text { (3) }\end{array}$ & $\begin{array}{l}n r k \\
(4) \\
\end{array}$ & $\begin{array}{c}\text { gpr/y } \\
(5) \\
\end{array}$ & $\begin{array}{c}n p r / y \\
(6)\end{array}$ \\
\hline \multicolumn{7}{|c|}{ Instruments: $c w b$} \\
\hline$e w$ & $\begin{array}{l}1.862 \\
(0.85)\end{array}$ & $\begin{array}{c}-0.437 \\
(-1.61)\end{array}$ & $\begin{array}{c}0.061 \\
(0.15)\end{array}$ & $\begin{array}{l}2.489 \\
(0.95)\end{array}$ & $\begin{array}{c}-0.445 \\
(-1.63)\end{array}$ & $\begin{array}{c}0.073 \\
(0.16)\end{array}$ \\
\hline$c w b$ & $\begin{array}{c}-2.186 \\
(-2.41) \\
\end{array}$ & & & $\begin{array}{r}-1.997 \\
(-2.24) \\
\end{array}$ & $\begin{array}{c}-2.146 \\
(-2.40) \\
\end{array}$ & $\begin{array}{c}-2.0184 \\
(-2.18) \\
\end{array}$ \\
\hline First-stage $R^{2}$ & 0.60 & & & 0.62 & 0.60 & 0.60 \\
\hline F-test (p-value) & 0.019 & & & 0.030 & 0.019 & 0.033 \\
\hline Countries (obs.) & $16(69)$ & & & $15(68)$ & $16(69)$ & $16(69)$ \\
\hline \multicolumn{7}{|c|}{ Instruments: $c w b$, servemp } \\
\hline$e w$ & $\begin{array}{l}2.275 \\
(1.08)\end{array}$ & $\begin{array}{c}-0.344 \\
(-1.43)\end{array}$ & $\begin{array}{c}-0.108 \\
(-0.34)\end{array}$ & $\begin{array}{l}2.626 \\
(1.10)\end{array}$ & $\begin{array}{c}-0.360 \\
(-1.43)\end{array}$ & $\begin{array}{r}-0.169 \\
(-0.50)\end{array}$ \\
\hline$c w b$ & $\begin{array}{c}-2.141 \\
(2.02)\end{array}$ & & & $\begin{array}{c}-2.050 \\
(-1.99)\end{array}$ & $\begin{array}{c}-2.073 \\
(-1.94)\end{array}$ & $\begin{array}{r}-1.970 \\
(-1.78)\end{array}$ \\
\hline servemp & $\begin{array}{c}-0.329 \\
(-1.07) \\
\end{array}$ & & & $\begin{array}{r}-0.304 \\
(-1.04) \\
\end{array}$ & $\begin{array}{c}-0.319 \\
(-1.03) \\
\end{array}$ & $\begin{array}{r}-0.322 \\
(-1.07)\end{array}$ \\
\hline J-statistic & 0.69 & 0.69 & 0.17 & 0.71 & 0.69 & 0.18 \\
\hline First-stage $R^{2}$ & 0.61 & & & 0.63 & 0.61 & 0.62 \\
\hline F-test (p-value) & 0.084 & & & 0.101 & 0.107 & 0.137 \\
\hline Countries (obs.) & $15(60)$ & & & $15(60)$ & $15(60)$ & $15(60)$ \\
\hline \multicolumn{7}{|c|}{ Instruments: occinj, lfratio } \\
\hline$e w$ & $\begin{array}{c}-1.173 \\
(-1.09)\end{array}$ & $\begin{array}{c}-0.166 \\
(-1.03)\end{array}$ & $\begin{array}{r}-0.139 \\
(-0.58)\end{array}$ & $\begin{array}{c}-0.935 \\
(-0.80)\end{array}$ & $\begin{array}{r}-0.175 \\
(-1.08)\end{array}$ & $\begin{array}{c}-0.130 \\
(-0.55)\end{array}$ \\
\hline occinj & $\begin{array}{l}2.048 \\
(2.54)\end{array}$ & & & $\begin{array}{l}1.748 \\
(2.20)\end{array}$ & $\begin{array}{l}2.201 \\
(2.48)\end{array}$ & $\begin{array}{l}2.045 \\
(2.23)\end{array}$ \\
\hline Ifratio & $\begin{array}{l}1.401 \\
(2.05) \\
\end{array}$ & & & $\begin{array}{l}1.564 \\
(2.22) \\
\end{array}$ & $\begin{array}{l}1.314 \\
(2.06)\end{array}$ & $\begin{array}{l}1.404 \\
(2.03) \\
\end{array}$ \\
\hline J-statistic & 0.69 & 0.20 & 0.74 & 0.91 & 0.22 & 0.74 \\
\hline First-stage $R^{2}$ & 0.62 & & & 0.67 & 0.63 & 0.62 \\
\hline F-test (p-value) & 0.014 & & & 0.041 & 0.020 & 0.020 \\
\hline Countries (obs.) & $14(39)$ & & & $13(38)$ & $14(39)$ & $14(39)$ \\
\hline
\end{tabular}

Note: See Table 2. Due to data availability the countries included are those of Tables 2, 4 and 5 with the exception of US, UK and Canada. 
FIGURE 1. Net returns on capital and excessive wages in OECD economies, 1970-2000

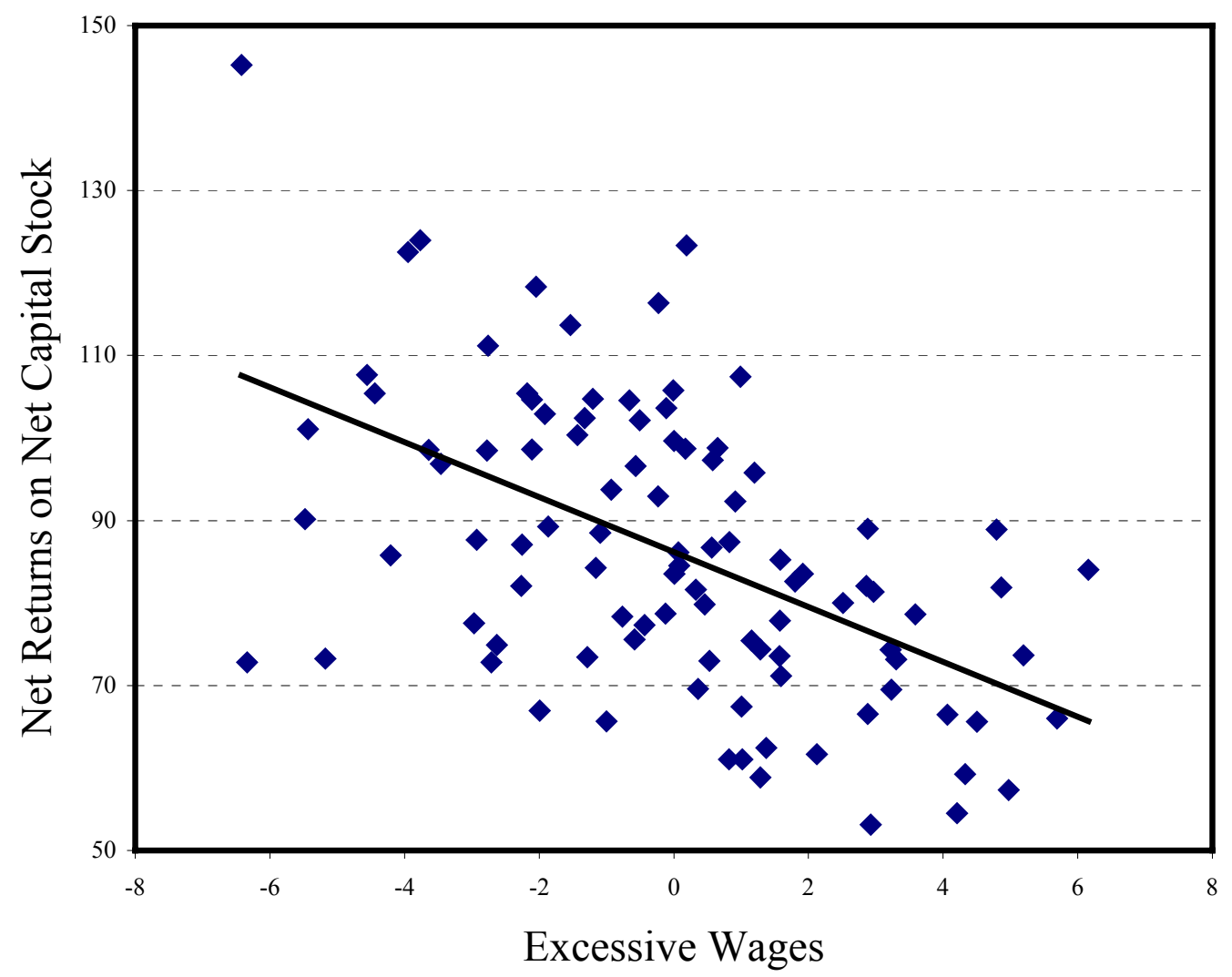

Source: AMECO and authors' calculations (see the text for the exact definition of the variables). 
FIGURE 2. Wages, productivity and profits

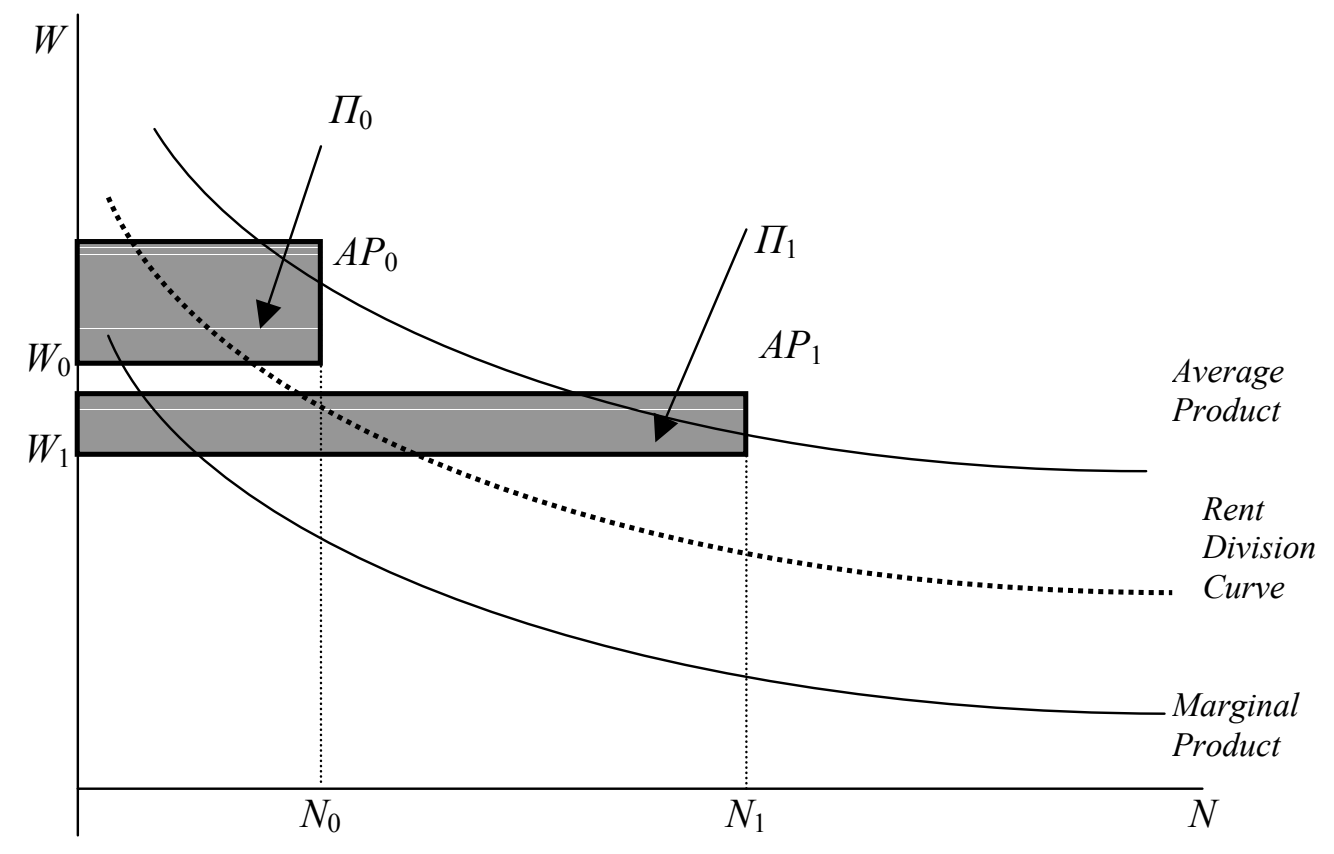




\section{CESifo Working Paper Series}

for full list see www.cesifo-group.org/wp

(address: Poschingerstr. 5, 81679 Munich, Germany, office@cesifo.de)

2741 Yan Dong and John Whalley, A Third Benefit of Joint Non-OPEC Carbon Taxes: Transferring OPEC Monopoly Rent, August 2009

2742 Valentina Bosetti, Carlo Carraro and Massimo Tavoni, Climate Change Mitigation Strategies in Fast-Growing Countries: The Benefits of Early Action, August 2009

2743 Christina Felfe, The Willingness to Pay for Job Amenities: Evidence from Mothers' Return to Work, August 2009

2744 Jörg Franke, Christian Kanzow, Wolfgang Leininger and Alexandra Väth, Effort Maximization in Asymmetric N-Person Contest Games, August 2009

2745 Bruno S. Frey and Paolo Pamini, Making World Heritage Truly Global: The Culture Certificate Scheme, August 2009

2746 Frank N. Caliendo, Is Social Security behind the Collapse of Personal Saving?, August 2009

2747 Caterina Liesegang and Marco Runkel, Corporate Income Taxation of Multinationals and Fiscal Equalization, August 2009

2748 Chrysovalantou Milliou and Apostolis Pavlou, Upstream Horizontal Mergers and Efficiency Gains, August 2009

2749 Rüdiger Pethig and Christian Wittlich, Interaction of Carbon Reduction and Green Energy Promotion in a Small Fossil-Fuel Importing Economy, August 2009

2750 Kai Carstensen, Oliver Hülsewig and Timo Wollmershäuser, Monetary Policy Transmission and House Prices: European Cross-country Evidence, August 2009

2751 Olaf Posch, Explaining Output Volatility: The Case of Taxation, August 2009

2752 Beatrice Scheubel, Daniel Schunk and Joachim Winter, Don't Raise the Retirement Age! An Experiment on Opposition to Pension Reforms and East-West Differences in Germany, August 2009

2753 Daniel G. Arce, Dan Kovenock and Brian Roberson, Suicide Terrorism and the Weakest Link, August 2009

2754 Mario Larch and Wolfgang Lechthaler, Comparative Advantage and Skill-Specific Unemployment, August 2009

2755 Horst Raff and Nicolas Schmitt, Buyer Power in International Markets, August 2009 
2756 Seppo Kari, Hanna Karikallio and Jukka Pirttilä, The Impact of Dividend Taxation on Dividends and Investment: New Evidence Based on a Natural Experiment, August 2009

2757 Mirco Tonin and Michael Vlassopoulos, Disentangling the Sources of Pro-social Behavior in the Workplace: A Field Experiment, August 2009

2758 Nicole Grunewald and Inmaculada Martínez-Zarzoso, Driving Factors of Carbon Dioxide Emissions and the Impact from Kyoto Protocol, August 2009

2759 Yu-Fu Chen and Michael Funke, Booms, Recessions and Financial Turmoil: A Fresh Look at Investment Decisions under Cyclical Uncertainty, August 2009

2760 Jan-Egbert Sturm and Jakob de Haan, Does Central Bank Communication really Lead to better Forecasts of Policy Decisions? New Evidence Based on a Taylor Rule Model for the ECB, August 2009

2761 Larry Karp, Sacrifice, Discounting and Climate Policy: Five Questions, August 2009

2762 Marianna Belloc and Samuel Bowles, International Trade, Factor Mobility and the Persistence of Cultural-Institutional Diversity, August 2009

2763 Charles Noussair and Fangfang Tan, Voting on Punishment Systems within a Heterogeneous Group, August 2009

2764 Birgit Bednar-Friedl and Karl Farmer, Internationally Coordinated Emission Permit Policies: An Option for Withdrawers from the Kyoto Protocol?, August 2009

2765 Pierre M. Picard and David E. Wildasin, Labor Market Pooling, Outsourcing and Labor Contracts, August 2009

2766 Stefan Voigt and Lorenz Blume, The Economic Effects of Federalism and Decentralization - A Cross-Country Assessment, August 2009

2767 David S. Jacks, Christopher M. Meissner and Dennis Novy, Trade Booms, Trade Busts, and Trade Costs, August 2009

2768 Mario Jametti and Thomas von Ungern-Sternberg, Hurricane Insurance in Florida, August 2009

2769 Alessandro Balestrino, Kind of Black: The Musicians' Labour Market in Italy, August 2009

2770 Yosr Abid Fourati and Cathal O’Donoghue, Eliciting Individual Preferences for Pension Reform, August 2009

2771 Christian Breuer and Chang Woon Nam, VAT on Intra-Community Trade and Bilateral Micro Revenue Clearing in the EU, August 2009

2772 Choudhry Tanveer Shehzad, Jakob De Haan and Bert Scholtens, Growth and Earnings Persistence in Banking Firms: A Dynamic Panel Investigation, August 2009 
2773 Erdal Yalcin, Uncertain Productivity Growth and the Choice between FDI and Export, August 2009

2774 Klaus Abberger, Wolfgang Nierhaus and Shynar Shaikh, Findings of the Signal Approach for Financial Monitoring in Kazakhstan, September 2009

2775 Sascha O. Becker, Francesco Cinnirella and Ludger Woessmann, The Trade-off between Fertility and Education: Evidence from before the Demographic Transition, September 2009

2776 Thomas Aronsson and Erkki Koskela, Optimal Income Taxation, Outsourcing and Policy Cooperation in a Dynamic Economy, September 2009

2777 Joel Slemrod, Old George Orwell Got it Backward: Some Thoughts on Behavioral Tax Economics, September 2009

2778 Cagri Seda Kumru and Athanasios C. Thanopoulos, Social Security Reform and Temptation, September 2009

2779 Alessandro Bucciol and Roel M. W. J. Beetsma, Inter- and Intra-generational Consequences of Pension Buffer Policy under Demographic, Financial and Economic Shocks, September 2009

2780 Eduardo Strube and Marcelo Resende, Complementarity of Innovation Policies in the Brazilian Industry: An Econometric Study, September 2009

2781 Henry Tulkens and Vincent van Steenberghe, "Mitigation, Adaptation, Suffering": In Search of the Right Mix in the Face of Climate Change, September 2009

2782 Maria L. Loureiro, Anna Sanz-de-Galdeano and Daniela Vuri, Smoking Habits: Like Father, Like Son, Like Mother, Like Daughter, September 2009

2783 Momi Dahan, Tehila Kogut and Moshe Shalem, Do Economic Policymakers Practice what they Preach? The Case of Pension Decisions, September 2009

2784 Eytan Sheshinski, Uncertain Longevity and Investment in Education, September 2009

2785 Nannette Lindenberg and Frank Westermann, How Strong is the Case for Dollarization in Costa Rica? A Note on the Business Cycle Comovements with the United States, September 2009

2786 Leif Danziger, Noncompliance and the Effects of the Minimum Wage on Hours and Welfare in Competitive Labor Markets, September 2009

2787 Gerlinde Fellner, Rupert Sausgruber and Christian Traxler, Testing Enforcement Strategies in the Field: Legal Threat, Moral Appeal and Social Information, September 2009

2788 Gabriel J. Felbermayr, Mario Larch and Wolfgang Lechthaler, Unemployment in an Interdependent World, September 2009 
2789 Sebastian G. Kessing, Federalism and Accountability with Distorted Election Choices, September 2009

2790 Daniel Gros, Global Welfare Implications of Carbon Border Taxes, September 2009

2791 Louis N. Christofides, Michael Hoy and Ling Yang, The Gender Imbalance in Participation in Canadian Universities (1977-2005), September 2009

2792 Jan K. Brueckner and Robert W. Helsley, Sprawl and Blight, September 2009

2793 Vidar Christiansen and Stephen Smith, Externality-correcting Taxes and Regulation, September 2009

2794 John Beirne, Guglielmo Maria Caporale, Marianne Schulze-Ghattas and Nicola Spagnolo, Global and Regional Spillovers in Emerging Stock Markets: A Multivariate GARCH-in-mean Analysis, September 2009

2795 Rüdiger Pethig and Frieder Kolleß, Asymmetric Capital-Tax Competition, Unemployment and Losses from Capital Market Integration, September 2009

2796 Ngo Van Long, Horst Raff and Frank Stähler, Innovation and Trade with Heterogeneous Firms, September 2009

2797 Margit Osterloh and Bruno S. Frey, Research Governance in Academia: Are there Alternatives to Academic Rankings?, September 2009

2798 Thiess Buettner and Clemens Fuest, The Role of the Corporate Income Tax as an Automatic Stabilizer, September 2009

2799 Annette Alstadsæter, Measuring the Consumption Value of Higher Education, September 2009

2800 Peter Friedrich, Chang Woon Nam and Janno Reiljan, Local Fiscal Equalization in Estonia: Is a Reform Necessary?, September 2009

2801 Evžen Kočenda and Jan Hanousek, State Ownership and Control in the Czech Republic, September 2009

2802 Michael Stimmelmayr, Wage Inequality in Germany: Disentangling Demand and Supply Effects, September 2009

2803 Biswa N. Bhattacharyay, Towards a Macroprudential Surveillance and Remedial Policy Formulation System for Monitoring Financial Crisis, September 2009

2804 Margarita Katsimi, Sarantis Kalyvitis and Thomas Moutos, "Unwarranted" Wage Changes and the Return on Capital, September 2009 